\title{
NORADRENERGIC DEFICITS CONTRIBUTE TO APATHY IN PARKINSON'S DISEASE THROUGH THE PRECISION OF EXPECTED OUTCOMES
}

Frank H. Hezemans ${ }^{1,2}$, Noham Wolpe ${ }^{1,3,4}$, Claire O’Callaghan ${ }^{3,5}$, Rong $\mathrm{Ye}^{2}$, Catarina Rua ${ }^{2}$, P. Simon Jones $^{2}$, Alexander G. Murley ${ }^{2}$, Negin Holland ${ }^{2}$, Ralf Regenthal ${ }^{6}$, Kamen A. Tsvetanov ${ }^{2,7}$, Roger A. Barker $^{8,9}$, Caroline H. Williams-Gray ${ }^{8}$, Trevor W. Robbins ${ }^{7,10}$, Luca Passamonti ${ }^{2,11}$, James B. Rowe $\mathrm{e}^{1,2}$

1 MRC Cognition and Brain Sciences Unit, University of Cambridge, United Kingdom

2 Department of Clinical Neurosciences and Cambridge University Hospitals NHS Trust, University of Cambridge, United Kingdom

3 Department of Psychiatry, University of Cambridge, United Kingdom

4 Department of Physical Therapy, Faculty of Medicine, Tel Aviv University, Israel.

5 Brain and Mind Centre and School of Medical Sciences, Faculty of Medicine and Health, University of Sydney, Australia

6 Division of Clinical Pharmacology, Rudolf-Boehm-Institute for Pharmacology and Toxicology, University of Leipzig, Germany

7 Department of Psychology, University of Cambridge, United Kingdom

8 John van Geest Centre for Brain Repair, Department of Clinical Neurosciences, University of Cambridge, United Kingdom

9 Wellcome - MRC Cambridge Stem Cell Institute, University of Cambridge, United Kingdom

10 Behavioural and Clinical Neuroscience Institute, University of Cambridge, United Kingdom

11 Istituto di Bioimmagini e Fisiologia Molecolare, Consiglio Nazionale delle Ricerche, Italy

Corresponding author:

Frank H. Hezemans

\section{Frank.Hezemans@mrc-cbu.cam.ac.uk}

MRC Cognition and Brain Sciences Unit

University of Cambridge

15 Chaucer Road

Cambridge CB2 7EF

United King This greprint reports new research that has not been certified by peer review and should not be used to guide clinical practice. 
medRxiv preprint doi: https://doi.org/10.1101/2021.07.04.21259922; this version posted July 6,2021 . The copyright holder for this preprint (which was not certified by peer review) is the author/funder, who has granted medRxiv a license to display the preprint in perpetuity.

It is made available under a CC-BY 4.0 International license .

\section{Abstract}

Apathy is a debilitating feature of many diseases, including Parkinson's disease. We tested the hypothesis that degeneration of the locus coeruleus-noradrenaline system contributes to apathy by modulating the relative weighting of prior beliefs about action outcomes. Participants with mild-tomoderate idiopathic Parkinson's disease ( $N=17)$ completed a double-blind, placebo-controlled, crossover study with $40 \mathrm{mg}$ of the noradrenaline reuptake inhibitor atomoxetine. Prior weighting was inferred from psychophysical analysis of performance in an effort-based visuomotor task, and was confirmed as negatively correlated with apathy. Locus coeruleus integrity was assessed in vivo using magnetisation transfer imaging at 7T. The effect of atomoxetine depended on locus coeruleus integrity: participants with a more degenerate locus coeruleus showed a greater increase in prior weighting on atomoxetine versus placebo. The results indicate a contribution of the noradrenergic system to apathy and potential benefit from noradrenergic treatment of people with Parkinson's disease, subject to stratification according to locus coeruleus integrity. 
medRxiv preprint doi: https://doi.org/10.1101/2021.07.04.21259922; this version posted July 6,2021 . The copyright holder for this preprint (which was not certified by peer review) is the author/funder, who has granted medRxiv a license to display the preprint in perpetuity.

It is made available under a CC-BY 4.0 International license .

Apathy is a common and debilitating feature of Parkinson's disease and other parkinsonian disorders (den Brok et al., 2015; Lanctôt et al., 2017; Lansdall et al., 2019; Starkstein et al., 2006). The reduction of goal-directed behaviour is typically attributed to dopamine-dependent loss of motivation (Levy \& Dubois, 2005; Marin, 1991; Robert et al., 2009), but it remains poorly understood. New treatments targeting apathy require mechanistic neurocognitive and psychopharmacological models (Passamonti et al., 2018).

Many psychopharmacological studies of apathy and Parkinson's disease focus on dopamine (Chong \& Husain, 2016), relating the striatal dopamine deficit in Parkinson's disease (Poewe et al., 2017) to the role of dopamine in reinforcement learning, along with value- and effort-based decision-making (Dabney et al., 2020; Niv et al., 2007; Schultz, 2015; Schultz et al., 1997). Apathetic individuals with Parkinson's disease exert less effort for a given reward, and acute withdrawal studies demonstrate a dopaminergic modulation of this effect (Chong et al., 2015; Le Bouc et al., 2016; Le Heron et al., 2018; Muhammed et al., 2016).

However, the dopaminergic model of apathy has limitations. First, apathy is positively correlated with impulsivity, which has been attributed to hyper-dopaminergic states (Chow et al., 2009; Drew et al., 2020; Lansdall et al., 2017; Murley et al., 2020; Petitet et al., 2021; Scott et al., 2020; Sinha et al., 2013). Second, apathy is common in Parkinson's disease patients despite dopamine replacement therapy, and may follow deep brain stimulation therapy (Zoon et al., 2021). There is no clear relationship between apathy severity and dopaminergic medication dose (den Brok et al., 2015; Sinha et al., 2013). Third, evidence from non-human animal models implicates non-dopaminergic neurotransmitter systems - in particular, noradrenaline - in motivation and effort-based decisionmaking (Bouret \& Richmond, 2015; Jahn et al., 2020; Varazzani et al., 2015).

The locus coeruleus is the principal source of noradrenaline in the brain (Moore \& Bloom, 1979; Szabadi, 2013). In Parkinson's disease, it undergoes early and severe pathological changes (Hawkes et al., 2010; Surmeier et al., 2017; Zarow et al., 2003), and this has been associated with certain cognitive and motivational problems that are insensitive to dopamine medication (Kehagia et al., 2014; Lewis et al., 2005; Loued-Khenissi \& Preuschoff, 2015; Passamonti et al., 2018; Tredici \& Braak, 2013).

It is proposed that noradrenaline signals the uncertainty of an individual's internal model of their environment. For example, phasic bursts of noradrenaline follow salient sensory inputs and promote behavioural adaptation (Bouret \& Sara, 2005; Dayan \& Yu, 2006), while tonic release of noradrenaline correlates with higher-order contextual features such as the volatility of the 
medRxiv preprint doi: https://doi.org/10.1101/2021.07.04.21259922; this version posted July 6,2021 . The copyright holder for this preprint (which was not certified by peer review) is the author/funder, who has granted medRxiv a license to display the preprint in perpetuity. It is made available under a CC-BY 4.0 International license .

environment or utility of a task, controlling the gain and selectivity of neural networks (Aston-Jones \& Cohen, 2005; Servan-Schreiber et al., 1990; Yu \& Dayan, 2005). Evidence from pharmacological manipulations and from pupillometry data (a surrogate marker of locus coeruleus activity; Joshi et al., 2016; Joshi \& Gold, 2020; Reimer et al., 2016) suggests that noradrenergic signalling indicates the extent to which sensory input is used to update existing beliefs and uncertainty of internal models (Jepma et al., 2016, 2018; Krishnamurthy et al., 2017; Lawson et al., 2021; Muller et al., 2019; Nassar et al., 2012). The ability to flexibly update internal models permits adaptive engagement with the environment - supporting goal-directed, motivated behaviour. Disruption in this ability is directly relevant to apathy.

We previously proposed that apathy is a result of the dependence of motivated behaviour on the relative precision of prior beliefs about action outcomes (Hezemans et al., 2020). With predictive processing, the brain optimises a probabilistic model of its environment, minimising 'surprise' or prediction error via action and perception - that is, active and passive inference (Friston, 2010; Friston et al., 2016; Ramstead et al., 2020). The balance between active and passive inference depends on the relative precision of prior beliefs and sensory evidence. When priors are held with high precision, they will be maintained despite conflicting (but imprecise) sensory evidence, and induce action to minimise the prediction error. That is, sensory evidence is changed by action to fulfil prior beliefs held with high precision (Adams et al., 2013; Friston et al., 2010; Tschantz et al., 2020; Wiese, 2017). If precision on the priors is not sufficiently high, passive inference occurs by adjusting perceptual priors, and no goal-directed action occurs.

The implication for apathy is that the loss of prior precision relative to sensory evidence would lead to a failure of action, because imprecise priors that conflict with sensory evidence are passively revised rather than actively fulfilled (Friston et al., 2010, 2014). There would be an apparent 'acceptance' of the state of the world, even if discordant with goals. In support of this hypothesis, trait apathy is negatively correlated with prior precision of outcomes: more apathetic individuals have less precise prior beliefs (Hezemans et al., 2020). Crucially, precision weighting is regulated by neurotransmitter systems that include noradrenaline (Friston et al., 2012; Moran et al., 2013; Parr \& Friston, 2017; Sales et al., 2019; Schwartenbeck et al., 2015).

This study tested the noradrenergic contributions to apathy in Parkinson's disease. We hypothesised that apathy is associated with reduced weighting of prior beliefs about action outcomes, and that this prior weighting is modulated by noradrenaline. We predicted baseline dependency of drug effects, such that the behavioural effect of a noradrenergic intervention depends on structural integrity of the 
medRxiv preprint doi: https://doi.org/10.1101/2021.07.04.21259922; this version posted July $6,2021$. The copyright holder for this preprint (which was not certified by peer review) is the author/funder, who has granted medRxiv a license to display the preprint in perpetuity.

It is made available under a CC-BY 4.0 International license.

locus coeruleus, in line with the inverted U-shaped dose-response curve of noradrenaline and other catecholamines (Aston-Jones \& Cohen, 2005; Cools, 2019; Holland et al., 2021; Robbins \& Arnsten, 2009). We tested this hypothesis in Parkinson's disease using an effortful goal-directed visuomotor task in combination with (i) modulation of noradrenaline using atomoxetine (a noradrenergic reuptake inhibitor) and (ii) measurement of structural integrity of the locus coeruleus via ultra-high field neuromelanin-sensitive magnetic resonance imaging. In view of the potential effect of atomoxetine on dopamine levels, control analyses included the levodopa equivalent daily dose and measurement of the substantia nigra contrast as covariates. 
medRxiv preprint doi: https://doi.org/10.1101/2021.07.04.21259922; this version posted July 6, 2021. The copyright holder for this preprint (which was not certified by peer review) is the author/funder, who has granted medRxiv a license to display the preprint in perpetuity. It is made available under a CC-BY 4.0 International license .

\section{RESULTS}

Participants with mild-to-moderate idiopathic Parkinson's disease $(N=17)$ completed a visuomotor task that involved effortful, goal-directed behaviour (Figure 1A). Their demographic and clinical details are outlined in Table 1. They completed this task twice in a double-blind, placebo-controlled, randomised within-subjects crossover design, receiving the selective noradrenaline reuptake inhibitor atomoxetine (40 mg oral dose) or placebo. A healthy control group ( $N=20$; age-, sex- and educationmatched to the Parkinson's disease group) undertook the task once on no medication to provide normative data. In view of baseline dependency of drug effects and the anticipated use of restorative pharmacology in patients but not healthy adults, the placebo-controlled drug intervention was restricted to those with Parkinson's disease. All participants underwent in vivo 7T MR imaging of the locus coeruleus using a magnetisation transfer weighted sequence in a baseline session, with atlas-based localisation of the locus coeruleus and contrast quantification (R. Ye et al., 2021). The participants with Parkinson's disease were on their regular anti-parkinsonian medication throughout the study. Table 1 provides an overview of the participant demographics; further details about the study design and clinical characteristics of the Parkinson's disease group are provided in the Methods and Supplementary Materials. 
medRxiv preprint doi: https://doi.org/10.1101/2021.07.04.21259922; this version posted July 6,2021 . The copyright holder for this preprint (which was not certified by peer review) is the author/funder, who has granted medRxiv a license to display the preprint in perpetuity.

It is made available under a CC-BY 4.0 International license.

Table 1 | Demographics and clinical characteristics of participants.

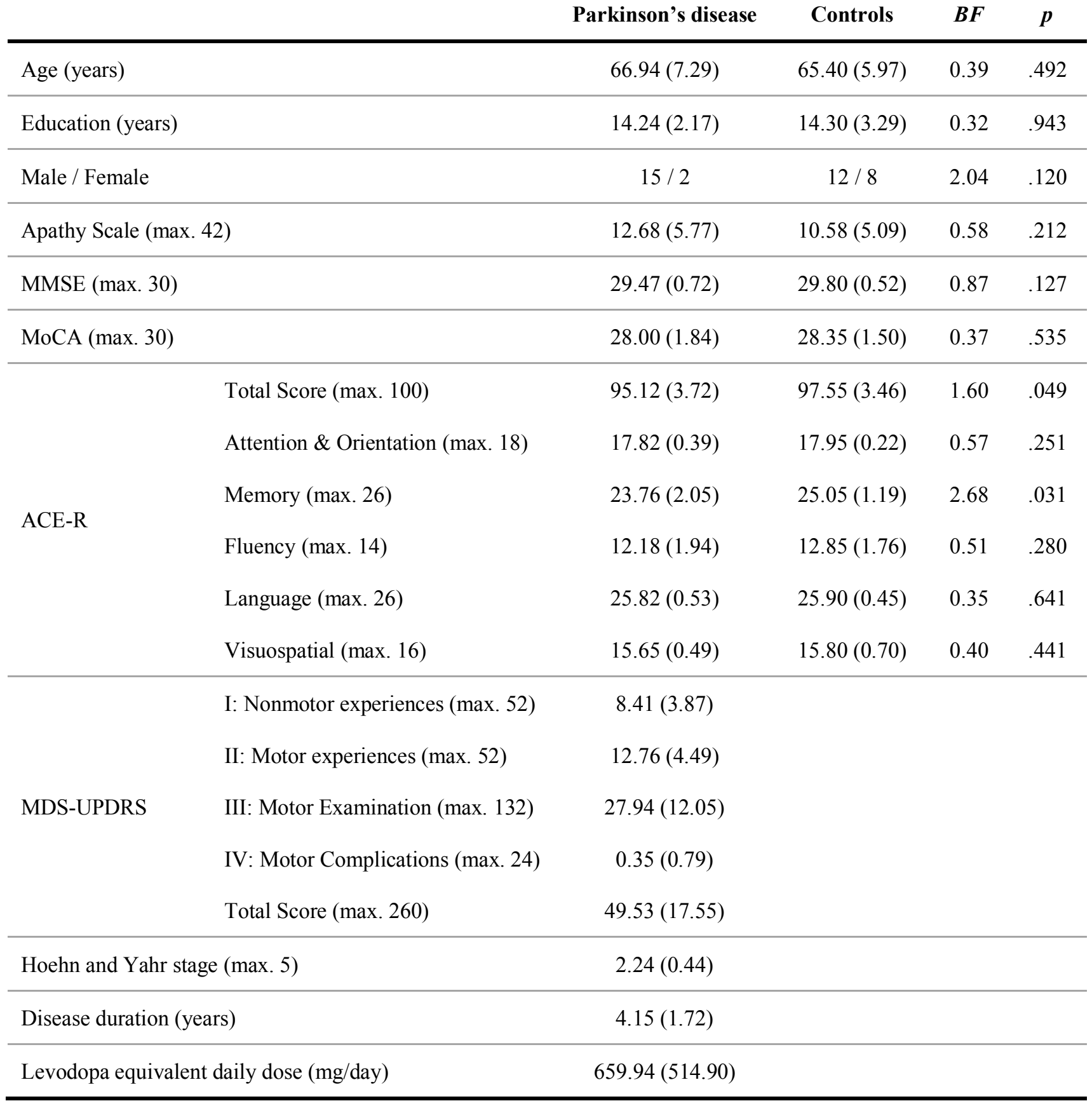

Note. Data are presented as mean (SD). Group comparisons were performed with independent samples t-tests or contingency tables as appropriate. The stated $p$-values are uncorrected; none survived $p<.05$ after correction for multiple comparisons. The participants with Parkinson's disease were tested on their regular medications. Levodopa equivalent daily dose was calculated based on Tomlinson et al. (2010). Apathy Scale refers to the total score for the self-rated version of the Starkstein et al. (1992) questionnaire. Abbreviations: BF, Bayes Factor for the alternative hypothesis over the null hypothesis, where $>3$ would indicate positive evidence in favour of a group difference; MMSE, Mini Mental State Examination; MoCA, Montreal Cognitive Assessment; ACE-R, Addenbrooke's Cognitive Examination - Revised; MDS-UPDRS, Movement Disorder Society-sponsored revision of the Unified Parkinson's Disease Rating Scale. 
medRxiv preprint doi: https://doi.org/10.1101/2021.07.04.21259922; this version posted July 6, 2021. The copyright holder for this preprint (which was not certified by peer review) is the author/funder, who has granted medRxiv a license to display the preprint in perpetuity.

It is made available under a CC-BY 4.0 International license .

\section{VISUOMOTOR TASK}

The visuomotor task was designed to estimate prior weighting, i.e. the relative precision of prior beliefs and sensory evidence in the perception of action outcomes. Using their dominant hand, participants pressed a force sensor to trigger a ballistic ball movement on the screen, aiming for the ball to stop on a target. The force exerted on the sensor (relative to the participant's maximum force, measured separately) directly determined the ball's final position. The difference between the ball's final position and the target constituted the performance error. For a subset of trials, the ball's trajectory was not shown, and participants were asked to estimate where the ball would have stopped, indicating their response on a grid of 12 response options (Figure 1A; see Methods for details). The difference between the participant's selected response option and the response option that was centred on the true final ball position constituted the estimation error. The linear relationship between estimation errors and performance errors was used to infer prior weighting (Figure 1B-C; see Methods for details).

We first tested for differences in basic task performance between drug conditions within the Parkinson's disease group (atomoxetine vs. placebo). We also tested the effect of group (Parkinson's disease on placebo vs. controls) noting the multiple differences between these groups, including the presence of Parkinson's disease, the placebo effect, and repetition effects.

We examined to what extent the force exerted on the force sensor matched the force required to stop the ball on target (force error; see Methods for details). Among the Parkinson's disease group there was no significant effect of atomoxetine on either the median force error $(\Delta$ drug: $\mathrm{M}=0.64 \%, \mathrm{SD}=$ $\left.1.84 \% ; t_{(16)}=1.44, p=.168 ; B F=0.60\right)$ or the interquartile range of force error $(\Delta$ drug: $\mathrm{M}=$ $\left.0.09 \%, \mathrm{SD}=2.59 \% ; t_{(16)}=-0.14, p=.892 ; B F=0.25\right)$. We found no significant differences between the Parkinson's disease and control groups, in terms of the median force error (controls: $M=0.69 \%$, $\mathrm{SD}=3.21 \% ; \mathrm{PD}$ placebo: $\left.\mathrm{M}=-0.48 \%, \mathrm{SD}=2.78 \% ; t_{(34.98)}=1.19, p=.242 ; B F=0.55\right)$ and the interquartile range of force error (controls: $\mathrm{M}=9.92 \%, \mathrm{SD}=3.73 \%$; $\mathrm{PD}$ placebo: $\mathrm{M}=9.19 \%, \mathrm{SD}=$ $\left.3.47 \% ; t_{(34.69)}=0.62, p=.540 ; B F=0.37\right)$. 
medRxiv preprint doi: https://doi.org/10.1101/2021.07.04.21259922; this version posted July 6,2021 . The copyright holder for this preprint (which was not certified by peer review) is the author/funder, who has granted medRxiv a license to display the preprint in perpetuity.

\section{A}

Action: Finger press controls ball trajectory, aiming at a target

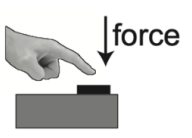

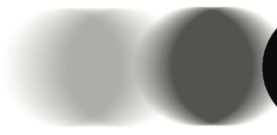

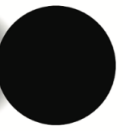

$K \longrightarrow$

performance error
B

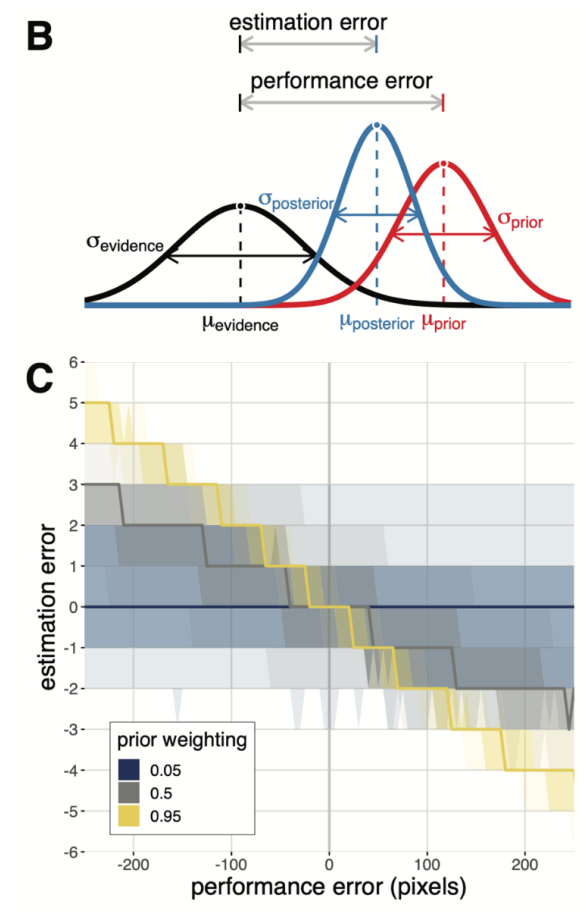

C

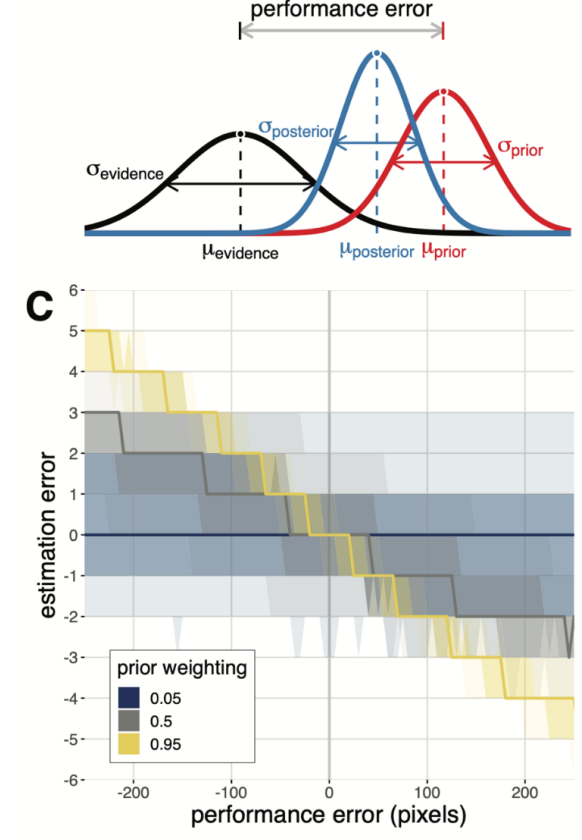

Estimation: Where would the ball have finished?

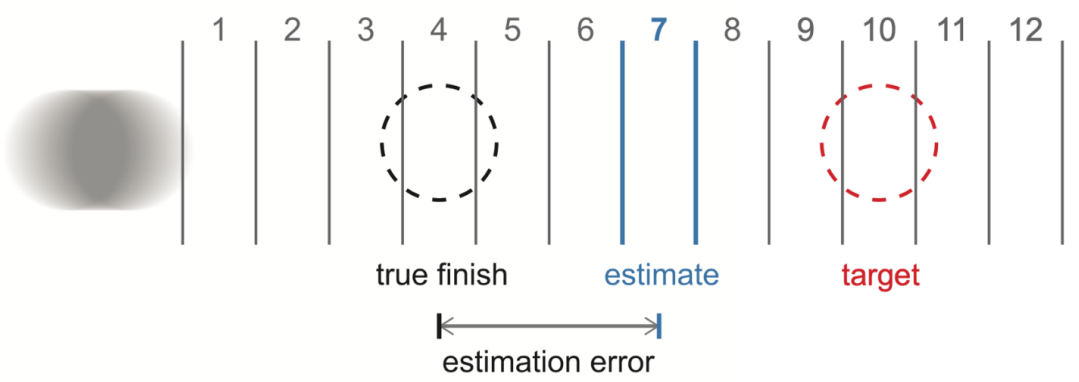

Figure 1 | Visuomotor task and Bayesian modelling approach. A) Participants performed a sustained finger press to trigger a ballistic ball trajectory, aiming it at a target. For the majority of trials, an animation of the ball trajectory was shown, and participants sought to minimise their performance error - the distance of the final ball position from the target (top row). For the remaining trials, the ball trajectory was hidden and participants were asked to estimate where the ball would have finished. Participants were given 12 evenly spaced response options, one of which was pseudorandomly selected to be centred on the true final ball position (i.e., the veridical response option). The difference between the chosen and veridical response option constitutes the estimation error (bottom row). B) Estimates of performance were modelled as a precision-weighted combination of a prior, centred on the target, and trial-wise sensory evidence, centred on the true final ball position. The relationship between estimation errors and performance errors is indicative of prior weighting - the precision of the prior relative to sensory evidence. C) Simulation demonstrating that prior weighting corresponds to the slope of the linear relationship between performance error and estimation error. For a given performance error and setting of prior weighting, the bold line represents the median predicted estimation error, and the increasingly transparent shaded areas represent the $25 \%$ and $50 \%$ quantile intervals of the predicted estimation error, respectively.

\section{PRIOR WEIGHTING AND APATHY}

We next examined participants' estimates of their own performance, to infer the relative weight afforded to prior beliefs in the perception of action outcomes. Participants combine their prior belief, centred on the target, with trial-wise sensory evidence, centred on the (hidden) true final ball position, to derive Bayes-optimal estimates of the ball's final position (Figure 1B). Assuming that the prior and sensory evidence are represented as Gaussian distributions with unknown variances $\sigma_{\text {prior }}^{2}$ and $\sigma_{\text {evidence, }}^{2}$, the optimal estimate for a given $\operatorname{trial} n\left(x_{\text {estimate }}^{(n)}\right)$ is a precision-weighted sum of the target position $x_{\text {target }}^{(n)}$ and the true final ball position $x_{\text {ball }}^{(n)}$ :

$$
x_{\text {estimate }}^{(n)}=w_{\text {prior }} \cdot x_{\text {target }}^{(n)}+\left(1-w_{\text {prior }}\right) \cdot x_{\text {ball }}^{(n)}
$$

where the prior weighting term $w_{\text {prior }}$ is given by: 
medRxiv preprint doi: https://doi.org/10.1101/2021.07.04.21259922; this version posted July 6, 2021. The copyright holder for this preprint (which was not certified by peer review) is the author/funder, who has granted medRxiv a license to display the preprint in perpetuity.

$$
w_{\text {prior }}=\frac{\sigma_{\text {evidence }}^{2}}{\sigma_{\text {evidence }}^{2}+\sigma_{\text {prior }}^{2}}
$$

By subtracting the true final ball position from both sides of Equation 1, we can express estimation errors as a function of performance errors:

$$
\underbrace{x_{\text {estimate }}^{(n)}-x_{\text {ball }}^{(n)}}_{\text {estimation error }}=-w_{\text {prior }} \cdot \underbrace{\left(x_{\text {ball }}^{(n)}-x_{\text {target }}^{(n)}\right)}_{\text {performance error }}
$$

Thus, the regression coefficient of estimation errors by performance errors corresponds to the negative of the prior weighting term (Vilares \& Kording, 2017; Wolpe et al., 2014). This is illustrated in Figure 1C using simulated data: higher values of prior weighting yield estimates that are strongly drawn towards the target and away from the true final ball position. When prior weighting approaches 1 , the estimation errors overwhelm the performance errors, reflecting a disregard for sensory evidence of poor performance. When prior weighting approaches 0 , the estimates are in line with the true performance. We used a linear mixed effects model to estimate the relationship between estimation error and performance error, allowing the slope (i.e., negative prior weighting) to vary for each testing session for each participant.

We confirmed that prior weighting was negatively associated with apathy, as measured by the Apathy Scale (AS; Starkstein et al., 1992). Prior weighting estimates from the Parkinson's disease group on placebo and the control group were regressed against apathy, group (Parkinson's disease vs. controls) and their interaction. To avoid confounding individual differences in prior weighting with basic task performance, we included the interquartile range of performance error as a covariate of no interest. We found a negative association between prior weighting and apathy, controlling for effects of group and performance error variability (Figure $2 \mathrm{~B} ; \beta=-0.35, \mathrm{SE}=0.15, t_{(32)}=-2.31, p=$ $.028 ; B F=2.30)$. This corroborates the negative relationship between prior weighting and trait apathy in a healthy young adults: more apathetic individuals show reduced prior weighting (Hezemans et al., 2020; Supplementary Materials). There was no group-wise difference in prior weighting between controls and patients on placebo (Figure $2 \mathrm{~A}$; controls: $\mathrm{M}=0.48, \mathrm{SD}=0.21$; $\mathrm{PD}$ placebo: $\mathrm{M}=0.45, \mathrm{SD}=0.26 ; \beta=0.03, \mathrm{SE}=0.15, t_{(32)}=0.20, p=.845 ; B F=0.41$ ), nor evidence for a group $\times$ apathy interaction effect $\left(\beta=0.17, \mathrm{SE}=0.15, t_{(32)}=1.08, p=.287 ; B F=0.60\right)$. 

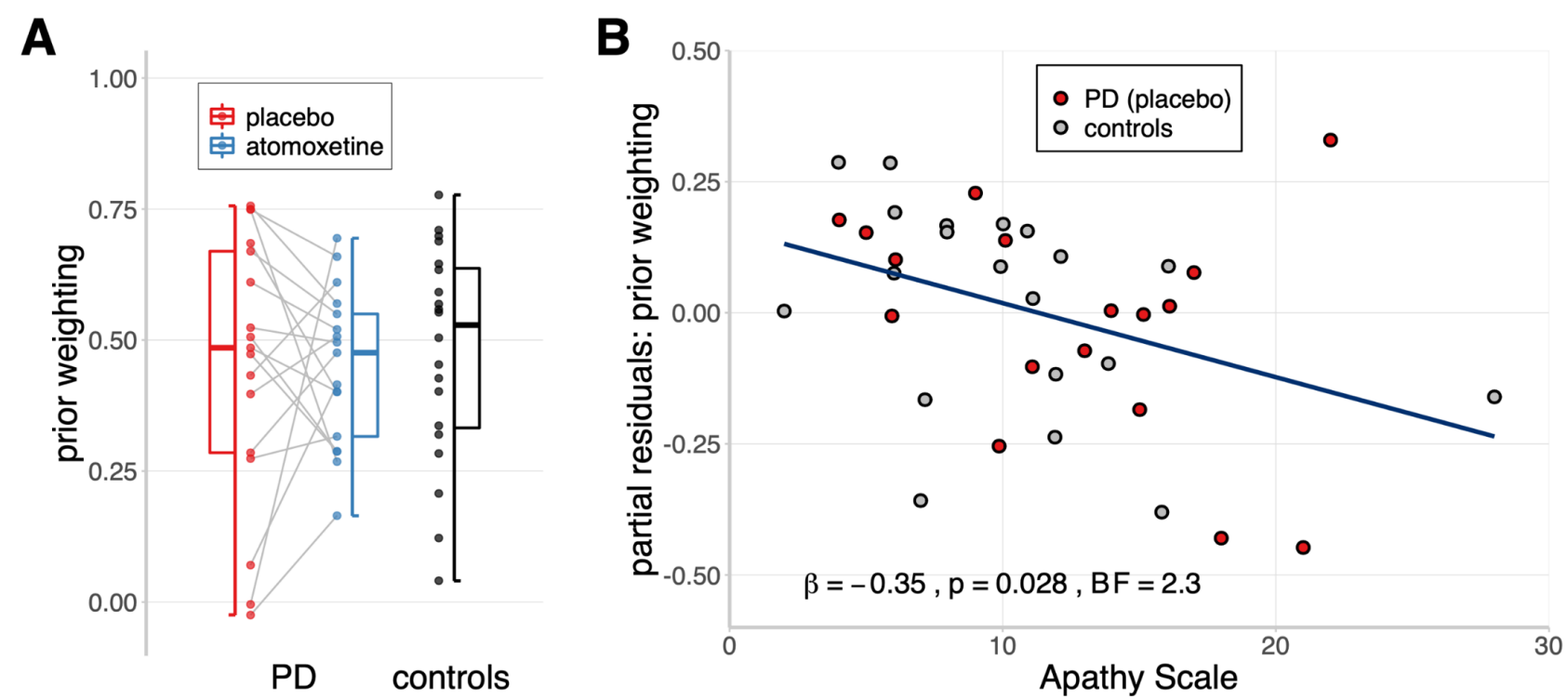

Figure 2 | Prior weighting and apathy. A) Estimates of prior weighting, obtained through a linear mixed effects model of estimation errors against performance errors. For the Parkinson's disease group, the grey lines indicate within-subject change in prior weighting from placebo to atomoxetine. Box-plot elements: centre line, median; box limits, first and third quartiles; whiskers, most extreme observations (all within $1.5 \times$ interquartile range from the box limits). B) The relationship between apathy and prior weighting, adjusted for the effects of group and task performance variability (i.e., partial residuals). Note that observations with identical questionnaire scores were horizontally jittered to avoid overlaid dots.

\section{PRIOR WEIGHTING AND NORADRENALINE}

Having established that prior weighting was associated with apathy, we tested whether atomoxetine affected prior weighting in the Parkinson's disease group (Figure 3A). On average across the group, there was no significant difference in prior weighting between the atomoxetine and placebo sessions (Figure 2A; $\Delta$ drug: $\mathrm{M}=-8.50 \times 10^{-4}, \mathrm{SD}=0.27 ; t_{(16)}=-0.01, p=.990 ; B F=0.25$ ). However, the between-subject variance in prior weighting was significantly reduced on atomoxetine relative to placebo (Pitman's test of equality of variance for paired data: $t_{(15)}=-2.24, p=.041 ; B F=2.46$ ), which suggests a baseline-dependent drug effect (Kelly \& Price, 2005).

We had predicted that the effect of atomoxetine depends on the structural integrity of the locus coeruleus, as indexed by its contrast to noise ratio (CNR; Figure 3B; see Methods for details). To test this, we entered prior weighting as the dependent variable in a linear mixed effects model with drug condition, locus coeruleus CNR and their interaction as fixed effects, the interquartile range of performance error as a covariate of no interest, and a random effect of participants on the intercept. We observed evidence for a significant interaction effect between the drug condition and locus coeruleus CNR (Figure 3C; $\beta=-0.38, \mathrm{SE}=0.14, F_{(1,15)}=7.91, p=.013 ; B F=10.02$ ), confirming that the effect of atomoxetine on prior weighting depended on locus coeruleus integrity. Specifically, 
medRxiv preprint doi: https://doi.org/10.1101/2021.07.04.21259922; this version posted July 6,2021 . The copyright holder for this preprint (which was not certified by peer review) is the author/funder, who has granted medRxiv a license to display the preprint in perpetuity.

It is made available under a CC-BY 4.0 International license.

the drug-induced change in prior weighting (atomoxetine vs. placebo) was negatively associated with locus coeruleus CNR, such that participants with lower locus coeruleus CNR tended to have a more positive change in prior weighting (Figure $3 \mathrm{D} ; r_{(15)}=-0.59, p=.013 ; B F=5.13$ ). There were no significant main effects of the drug condition $\left(\beta=-2.06 \times 10^{-3}, \mathrm{SE}=0.13, F_{(1,15)}=2.36 \times 10^{-4}, p=\right.$ $.988 ; B F=0.29)$ or locus coeruleus $\mathrm{CNR}\left(\beta=-0.08, \mathrm{SE}=0.20, F_{(1,14)}=0.16, p=.695 ; B F=0.43\right)$ on prior weighting.

A

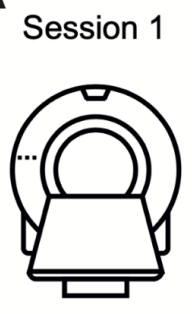

$7 T$ locus coeruleus
imaging

\section{Sessions $2 \& 3$}
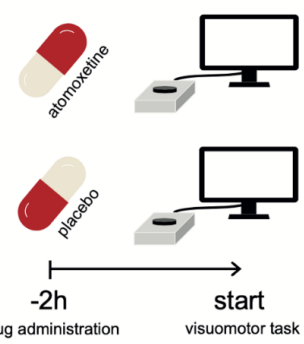

C

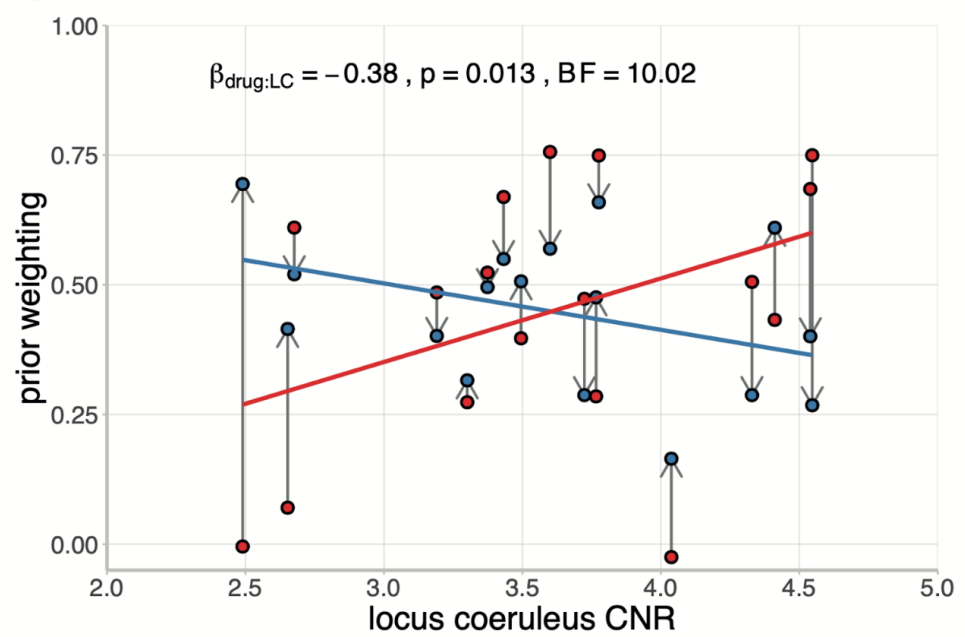

B

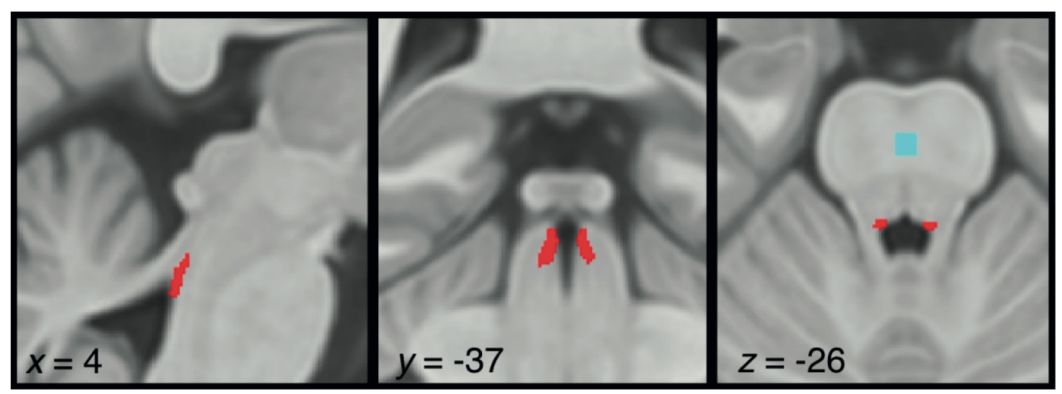

D

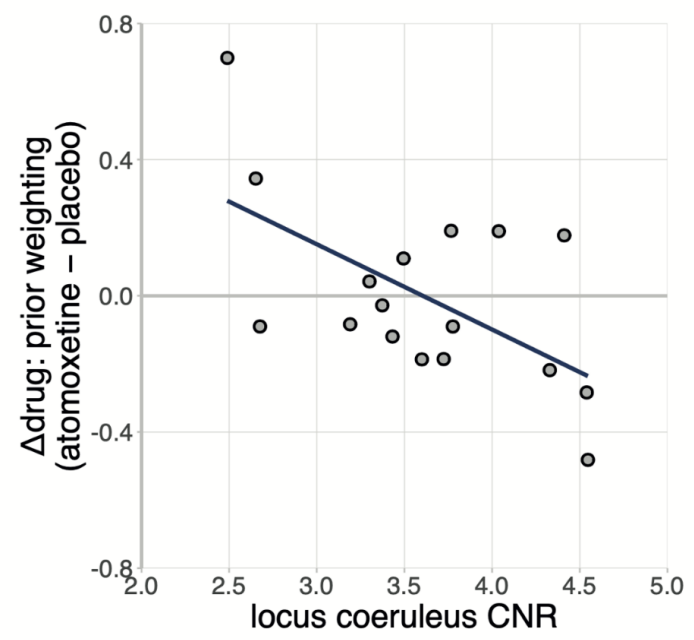

Figure 3 | Baseline-dependent effects of noradrenaline on prior weighting. A) Schematic overview of the noradrenergic drug study. The first session involved 7T MRI of the locus coeruleus, to estimate the mean contrast-tonoise ratio (CNR). The second and third sessions formed a double-blind randomised placebo-controlled crossover study, with $40 \mathrm{mg}$ of oral atomoxetine of placebo. Two hours after drug administration, participants performed the visuomotor task that was designed to estimate prior weighting. B) Study-specific independent locus coeruleus atlas (red) and reference region in the central pons (blue). Figure reused from O'Callaghan et al. (2021) under a CC-BY 4.0 license (https://creativecommons.org/licenses/by/4.0/). C) Estimates of prior weighting for participants with Parkinson's disease, plotted as a function of their locus coeruleus CNR and the drug condition. Within-subject change in prior weighting from placebo to atomoxetine is indicated by the grey arrows. D) The relationship between the drug-induced change in prior weighting (atomoxetine minus placebo) and locus coeruleus CNR. 
medRxiv preprint doi: https://doi.org/10.1101/2021.07.04.21259922; this version posted July $6,2021$. The copyright holder for this preprint (which was not certified by peer review) is the author/funder, who has granted medRxiv a license to display the preprint in perpetuity.

It is made available under a CC-BY 4.0 International license .

Supplementary analyses confirmed the robustness and specificity of the interaction effect between the drug condition and locus coeruleus CNR. First, using both frequentist and Bayesian model selection procedures, we found that this interaction persisted with additional covariates, including age, motor severity (UPDRS part III), levodopa equivalent daily dose, atomoxetine plasma level, and total intracranial volume (Supplementary Materials). Second, we used a linear mixed effects model with CNR extracted from the substantia nigra, as a neuromelanin-rich control region (Rua et al., 2021). There was no significant interaction effect between the drug condition and substantia nigra CNR on prior weighting $\left(\beta=0.16, \mathrm{SE}=0.16, F_{(1,15)}=0.94, p=.349 ; B F=0.71\right)$. Third, the interaction effect remained significant when using an alternative calculation for locus coeruleus contrast (contrast ratio to mean instead of $\mathrm{SD} ; \beta=-0.41, \mathrm{SE}=0.13, F_{(1,15)}=9.79, p=.007 ; B F=$ 17.40 ), or when using the more conservative $25 \%$ probability mask to derive the locus coeruleus $\mathrm{CNR}\left(\beta=-0.42, \mathrm{SE}=0.13, F_{(1,15)}=10.25, p=.006 ; B F=20.22\right)$. Fourth, re-fitting the original linear mixed effects model using a robust estimation method (Koller, 2016) yielded qualitatively similar results $\left(\beta=-0.38, \mathrm{SE}=0.15, t_{(15)}=-2.62, p=.019\right)$. Taken together, these findings underwrite the robustness and specificity of the drug $\times$ locus coeruleus CNR interaction.

\section{DECOMPOSITION OF NORADRENERGIC EFFECTS ON PRIOR WEIGHTING}

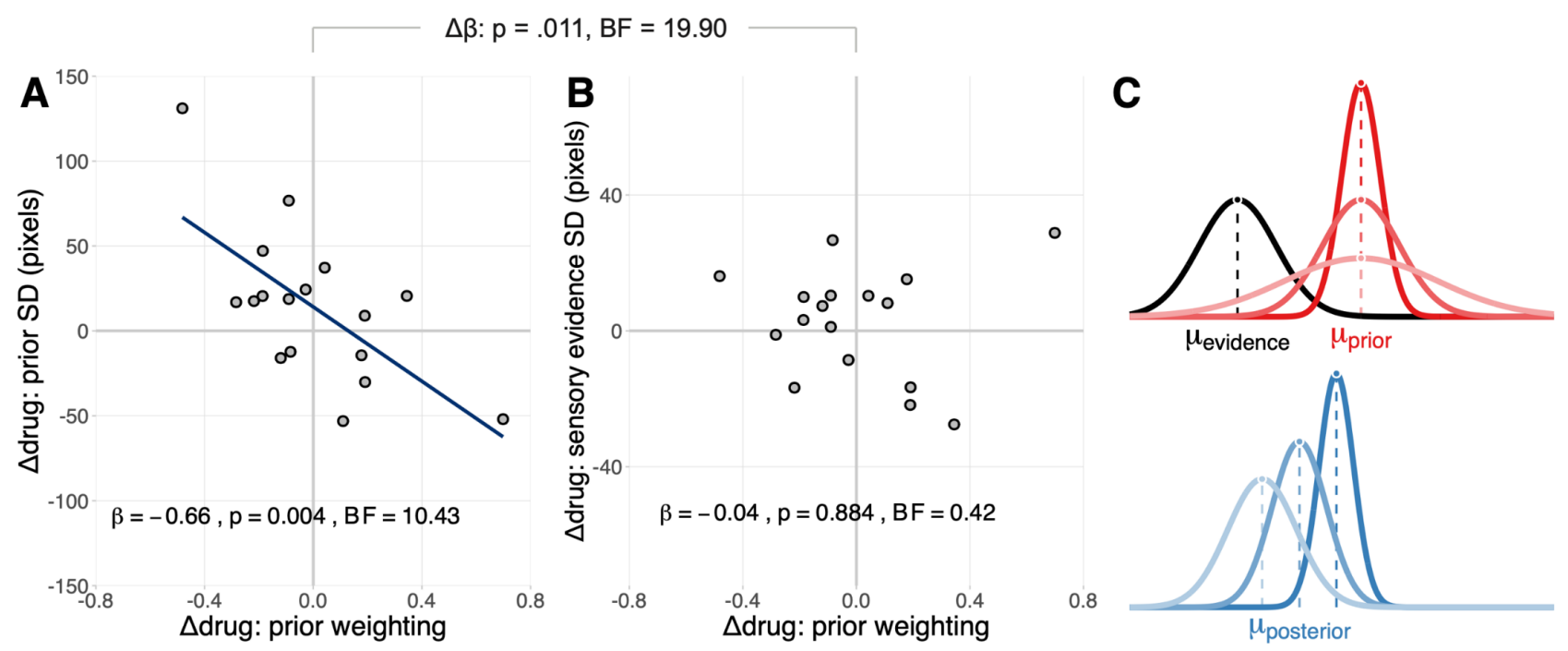

Figure 4 | Decomposition of noradrenergic effects on prior weighting. A-B) The relationship between the drug effect on prior weighting and Bayesian model estimates of the drug effect on the standard deviation of the prior distribution (A) and the standard deviation of the sensory evidence distribution (B). C) Schematic illustration of how the effect of atomoxetine on prior precision (red) determines the extent to which (posterior) estimates of performance (blue) are drawn towards the prior, for a given sensory evidence (black). Lighter shades of red represent less precise priors. The effect of prior precision on the posterior is illustrated with corresponding shades of blue. 
medRxiv preprint doi: https://doi.org/10.1101/2021.07.04.21259922; this version posted July 6,2021 . The copyright holder for this preprint (which was not certified by peer review) is the author/funder, who has granted medRxiv a license to display the preprint in perpetuity.

It is made available under a CC-BY 4.0 International license .

As prior weighting represents the precision of the prior relative to the sensory evidence (Equation 2), drug-induced changes in prior weighting could in principle be explained by changes in prior precision, sensory evidence precision, or both. We therefore fitted the Parkinson's disease group data with a hierarchical Bayesian model that decomposed the drug effect on prior weighting into separate drug effects on the standard deviation of the prior and sensory evidence distributions (see Methods for details). The drug effect on the standard deviation of the prior was significantly associated with the drug effect on prior weighting (Figure $4 \mathrm{~A} ; \beta=-0.66, \mathrm{SE}=0.19, t_{(15)}=-3.41, p=.004 ; B F=$ 10.43). This relationship was negative, such that those participants who had reduced prior weighting on atomoxetine, tended to have greater standard deviation of the prior (i.e., reduced prior precision). In contrast, there was no significant relationship between the drug effect on the standard deviation of sensory evidence and the drug effect on prior weighting (Figure $4 \mathrm{~B} ; \beta=-0.04, \mathrm{SE}=0.26, t_{(15)}=$ $0.15, p=.884 ; B F=0.42$ ).

To directly test whether the drug effect on prior weighting was more strongly associated with the drug effect on prior precision than the drug effect on sensory evidence precision, we performed a repeated-measures ANCOVA with the drug effect on prior weighting as a between-subjects covariate, the precision term (prior vs. sensory evidence) as the within-subjects factor, and the estimated drug effects on prior and sensory evidence precision as the dependent variable. We found a significant interaction between the precision term and the drug effect on prior weighting $\left(F_{(1,15)}=\right.$ $8.34, p=.011 ; B F=19.90)$, confirming that the relationships with the drug effects on prior and sensory evidence precision were significantly different from each other. We obtained similar results using a 'plausible values' analysis approach (Ly et al., 2017) that accounts for uncertainty in the parameter estimates (Supplementary Materials).

Overall, these results suggest that the atomoxetine-induced change in prior weighting was primarily explained by changes in prior precision, and not by changes in sensory evidence precision (Figure 4C).

\section{APATHY MODERATES NORADRENERGIC EFFECTS ON PRIOR WEIGHTING}

Lastly, given the relationship between prior weighting and apathy (Figure 2A), we tested whether the effect of locus coeruleus integrity on the atomoxetine-induced change in prior weighting varied according to the observed apathy. We regressed the drug effect on prior weighting against locus coeruleus CNR, apathy, and their interaction. We observed a significant interaction effect between locus coeruleus $\mathrm{CNR}$ and apathy $\left(\beta=-0.49, \mathrm{SE}=0.21, t_{(13)}=-2.34, p=.036 ; B F=2.54\right)$, such that greater apathy was associated with a stronger (i.e. more negative) relationship between locus 
medRxiv preprint doi: https://doi.org/10.1101/2021.07.04.21259922; this version posted July 6,2021 . The copyright holder for this preprint (which was not certified by peer review) is the author/funder, who has granted medRxiv a license to display the preprint in perpetuity.

It is made available under a CC-BY 4.0 International license .

coeruleus CNR and atomoxetine's effect on prior weighting (Figure 5A). Specifically, the JohnsonNeyman procedure (Bauer \& Curran, 2005) indicated that the regression coefficient of locus coeruleus CNR was significant when the Apathy Scale score was above 12 (Figure 5B). This significance threshold approximates the commonly used threshold for clinically significant apathy (14 or higher; Starkstein et al., 1992). These results suggest that the baseline-dependent noradrenergic effects on prior weighting is more likely to be observed among those participants who were apathetic. However, we note that the Bayes Factor of the interaction effect was "anecdotal".

A

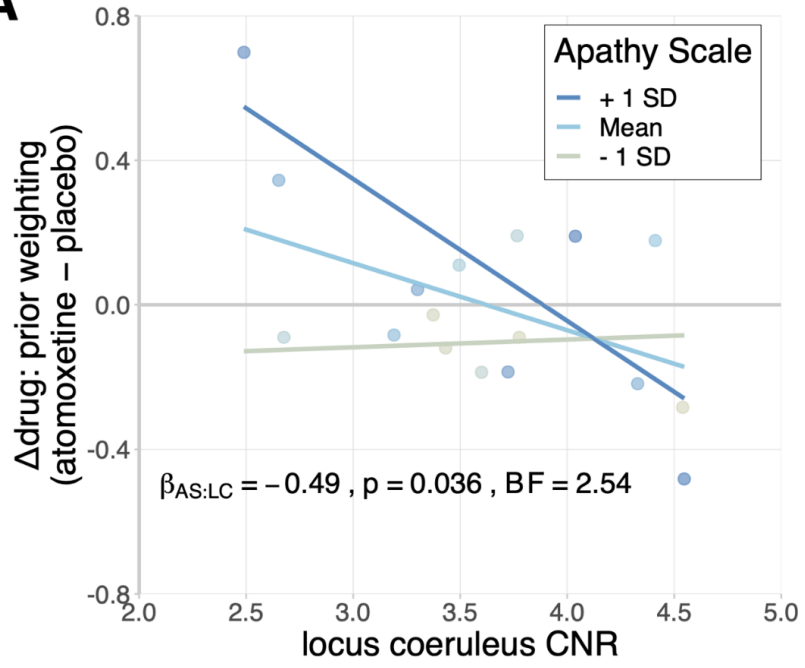

B

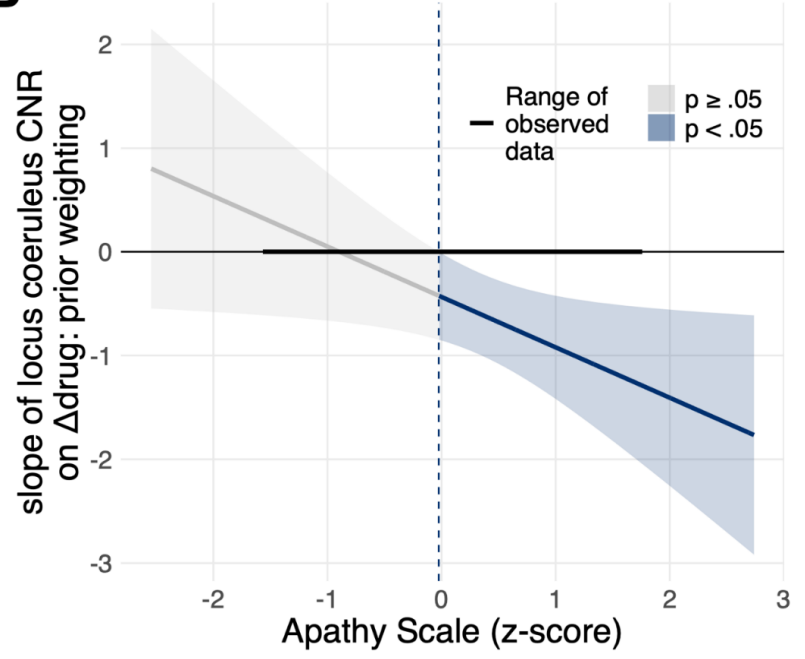

Figure 5 | Baseline-dependent noradrenergic effects on prior weighting are moderated by apathy. A) The relationship between the drug effect on prior weighting and locus coeruleus CNR, plotted separately for above-average, average, and below-average scores on the Apathy Scale. Note that the Apathy Scale was treated as a continuous predictor in the reported statistical analyses, and is only discretised for visualisation purposes. B) Jonhson-Neyman interval plot, illustrating the range of scores on the Apathy Scale for which the regression coefficient of locus coeruleus CNR on the drug effect on prior weighting was statistically significant. The grey and blue shaded areas represent the $95 \%$ confidence interval for the predicted regression coefficient of locus coeruleus CNR, given the Apathy Scale score. The Apathy Scale scores ( $\mathrm{x}$-axis) were $\mathrm{z}$-scored to facilitate interpretation of the regression coefficient (y-axis); the significance threshold of $\mathrm{z}=-0.02$ (blue dashed line) corresponded to a score of 12.3. 
medRxiv preprint doi: https://doi.org/10.1101/2021.07.04.21259922; this version posted July 6,2021 . The copyright holder for this preprint (which was not certified by peer review) is the author/funder, who has granted medRxiv a license to display the preprint in perpetuity.

\section{DISCUSSION}

This study provides evidence that the locus coeruleus noradrenergic system regulates the balance between prior beliefs and sensory evidence for goal-directed behaviour, and its impairment contributes to apathy. Individual differences in the relative weight afforded to prior beliefs were negatively associated with apathy, such that more apathetic individuals had reduced prior weighting. Atomoxetine modulated this prior weighting in a baseline-dependent manner in people with Parkinson's disease. Specifically, people with reduced locus coeruleus integrity had a greater increase in prior weighting after atomoxetine, relative to a placebo. Using hierarchical Bayesian modelling, we demonstrated that this drug-induced change in prior weighting was primarily explained by changes in the precision of prior beliefs, and not by changes in the precision of sensory evidence. These results highlight the link between the noradrenergic locus coeruleus and the control of prior precision, during goal-directed behaviour. Given the early loss of noradrenergic cells in the locus coeruleus by Parkinson's disease, this association suggests a contributory mechanism to apathy in Parkinson's disease.

We propose that increased weighting of prior beliefs following atomoxetine may help alleviate apathy. According to Bayesian models of brain function, actions require prior beliefs about their outcomes to be held with relatively high precision (Adams et al., 2013; Brown et al., 2013; Friston, 2010). In Parkinson's disease, the relative precision of predictive signals is compromised (Macerollo et al., 2016; Wolpe et al., 2018), which underlies the poverty of action selection and increased reliance on external cues for the initiation and maintenance of movement (Azulay et al., 1999; Klockgether \& Dichgans, 1994; Thaut et al., 1996). By restoring the precision of prior beliefs, atomoxetine may help attenuate disruptive sensory input (Conte et al., 2013; Konczak et al., 2012) and minimise the unnecessary updating of prior beliefs in light of spurious prediction errors (Moran et al., 2014; Wolpe et al., 2016). Thus, atomoxetine could confer a benefit to Parkinson's disease patients with reduced noradrenergic capacity, by restoring the reliance on the predictive signals that are necessary for goal-directed behaviour.

Several previous studies have emphasised that the effects of catecholaminergic drugs - including atomoxetine - depend on individual differences in the baseline levels of activity of the ascending neuromodulatory systems (Aston-Jones \& Cohen, 2005; Cools, 2019; Holland et al., 2021; Robbins \& Arnsten, 2009). However, without specific estimates of locus coeruleus integrity or noradrenergic capacity, heterogeneity in the response to atomoxetine is difficult to interpret (e.g. Jepma et al., 2016; Z. Ye et al., 2016). Here, we used ultra-high field imaging to directly quantify the structural 
medRxiv preprint doi: https://doi.org/10.1101/2021.07.04.21259922; this version posted July 6,2021 . The copyright holder for this preprint (which was not certified by peer review) is the author/funder, who has granted medRxiv a license to display the preprint in perpetuity.

It is made available under a CC-BY 4.0 International license .

integrity of the locus coeruleus in individuals with Parkinson's disease. Our results indicate that individuals with a more severely degenerated locus coeruleus had a stronger increase in prior weighting following a single dose of atomoxetine, whereas individuals with a relatively preserved locus coeruleus had no meaningful change or even a reduction in prior weighting. These results are consistent with an inverted-U shaped curve of neurotransmitter function, whereby intermediate levels of activity are associated with optimal performance, while hypo- or hyperactive levels lead to suboptimal behaviour (Aston-Jones \& Cohen, 2005; Cools \& D'Esposito, 2011; Robbins, 2000).

The relationship between locus coeruleus integrity and the drug-induced change in prior weighting varied according to the observed apathy. For less apathetic individuals, there was generally no meaningful effect of atomoxetine on prior weighting, and no clear relationship between locus coeruleus integrity and the drug's effect. In contrast, among more apathetic individuals, we observed a clear baseline-dependent effect of atomoxetine on prior weighting. These results underwrite the multifactorial nature of catecholaminergic drug effects in Parkinson's disease, with complex interactions between the baseline neuromodulatory state and behavioural symptoms (Cools, 2019; Meder et al., 2019). They also highlight the importance of locus coeruleus imaging for informing noradrenergic therapy: among individuals with apathy, the cognitive effects of atomoxetine varied as a function of locus coeruleus integrity.

Our results inform theoretical models of noradrenergic function. According to the adaptive gain theory (Aston-Jones \& Cohen, 2005), dynamic shifts between predominantly phasic or tonic modes of locus coeruleus activity modulate the gain of task-relevant brain networks at different timescales, and thereby regulate the balance between task engagement and disengagement (Gilzenrat et al., 2010; Jepma \& Nieuwenhuis, 2011; McClure et al., 2006; Nieuwenhuis et al., 2005). Phasic bursts of locus coeruleus activity, time-locked to task-relevant events, are proposed to induce an adaptive sampling bias, increasing the salience of prepotent representations while inhibiting weaker competing representations. In contrast, persistently elevated (tonic) locus coeruleus activity increases the salience of representations indiscriminately, encouraging task disengagement and exploration (Aston-Jones \& Cohen, 2005; see also Yu \& Dayan, 2005). It is possible that individuals with reduced locus coeruleus integrity increase the phasic-to-tonic firing ratio following atomoxetine (Bari \& Aston-Jones, 2013), whereas individuals with preserved locus coeruleus integrity were shifted into a predominantly tonic mode of firing. On this basis, an atomoxetine-induced increase in phasic locus coeruleus activity would cause inferences about task performance to be dominated by "optimistic" priors (Wolpe et al., 2014), neglecting sensory evidence for subtle deviations from this prior (Eldar et al., 2013; Hauser et al., 2017; Warren et al., 2016). Although this interpretation of the 
medRxiv preprint doi: https://doi.org/10.1101/2021.07.04.21259922; this version posted July 6,2021 . The copyright holder for this preprint (which was not certified by peer review) is the author/funder, who has granted medRxiv a license to display the preprint in perpetuity. It is made available under a CC-BY 4.0 International license .

atomoxetine-induced changes in prior weighting remains to be directly tested, it is supported by several lines of evidence. The anterior cingulate and dorsomedial frontal cortex are associated with mechanisms of belief updating (Behrens et al., 2007; Jocham et al., 2009; McGuire et al., 2014; Muller et al., 2019; O'Reilly et al., 2013). Reciprocal connections between these regions and the locus coeruleus (Arnsten \& Goldman-Rakic, 1984; Aston-Jones \& Cohen, 2005) might therefore enable noradrenergic modulation of the reliance on internal models for action (Tervo et al., 2014). In Parkinson's disease, locus coeruleus degeneration is accompanied by reduced noradrenaline levels in the forebrain (Cash et al., 1987; Pifl et al., 2012; Scatton et al., 1983). Atomoxetine increases extracellular noradrenaline levels across the brain - including a three-fold increase in the prefrontal cortex - by inhibiting the presynaptic noradrenaline transporter (Bymaster et al., 2002; Swanson et al., 2006). Thus, for individuals with severe locus coeruleus degeneration, atomoxetine may help alleviate the dysfunctional modulation of prefrontal noradrenergic targets, and thereby help restore the precision of prefrontal representations of predictive signals.

This study has limitations. First, although we collected a comprehensive dataset for each individual participant, incorporating various demographic, behavioural, and neuropharmacological measures, the total number of participants is modest. Our study was therefore prone to type II error for frequentist identification of small effects. We mitigate this using complementary Bayesian statistics, enabling inferences on the null hypotheses as well as for the alternative hypotheses. Second, we acknowledge the psychopharmacological complexity of medicated Parkinson's disease patients and atomoxetine. In addition to its noradrenergic effects, atomoxetine increases extracellular dopamine levels in the prefrontal cortex (Bymaster et al., 2002). Atomoxetine might interact with the patients' regular dopaminergic medication, since some dopamine uptake is mediated by the noradrenaline transporter (Seamans \& Yang, 2004; Wayment et al., 2001) and locus coeruleus activity can result in co-release of noradrenaline and dopamine (Devoto et al., 2001, 2005). We cannot exclude the possibility that atomoxetine-induced changes in prior weighting partially reflected dopaminergic effects. However, we note that the integrity of the substantia nigra yielded null results in the model, and including levodopa equivalent daily dose (LEDD) as a covariate did not change the interaction between the drug condition and locus coeruleus CNR on prior weighting. Previous studies similarly found no evidence that the effect of atomoxetine in Parkinson's disease depends on individual differences in LEDD (e.g. Kehagia et al., 2014; Rae et al., 2016; Z. Ye et al., 2015). It is possible that the changes in prior weighting are related to atomoxetine-induced changes in arousal (Berridge $\&$ Waterhouse, 2003). Atomoxetine can have mild sedative effects, increasing omission errors and decreasing response accuracy specifically in the context of rapid stimulus presentation (Toschi et al., 
medRxiv preprint doi: https://doi.org/10.1101/2021.07.04.21259922; this version posted July $6,2021$. The copyright holder for this preprint (which was not certified by peer review) is the author/funder, who has granted medRxiv a license to display the preprint in perpetuity.

It is made available under a CC-BY 4.0 International license .

2021). However, atomoxetine did not affect basic task performance in the current study or in a stopsignal task, either at the group-average level or in relation to individual differences in locus coeruleus CNR (O’Callaghan et al., 2021). This argues against a simple effect via arousal.

We designed this study to test a mechanistic hypothesis about the noradrenergic regulation of sensorimotor integration in Parkinson's disease. It was not a clinical trial, and we did not focus on clinical outcomes. Further studies are needed to determine if atomoxetine can improve everyday functioning of people with Parkinson's disease, incorporating patient-, carer- and clinician-rated assessments as well as experimental paradigms (Lansdall et al., 2017; Murley et al., 2020). Our results suggest that patients with significant apathy may benefit from noradrenergic treatment, informing future stratified clinical trials.

In conclusion, this study provides evidence for a noradrenergic role in apathy in Parkinson's disease, via the precision weighting of prior beliefs about action outcomes. We suggest that these results support a Bayesian account of apathy as a failure of active inference, resulting from impaired noradrenergic precision of priors for action. The noradrenergic modulation of prior precision may help explain dopamine-insensitive cognitive deficits in Parkinson's disease, including apathy. Locus coeruleus imaging may offer a useful marker of noradrenergic function that can inform new stratified trials of noradrenergic therapies in selected patients with Parkinson's disease. 
medRxiv preprint doi: https://doi.org/10.1101/2021.07.04.21259922; this version posted July 6,2021 . The copyright holder for this preprint (which was not certified by peer review) is the author/funder, who has granted medRxiv a license to display the preprint in perpetuity.

\section{METHODS}

The current study was part of a broader project on the noradrenergic mechanisms of cognitive and motivational problems in Parkinson's disease, including response inhibition deficits, as reported in O'Callaghan et al. (2021). Therefore, the following description of the participants, study procedure, and locus coeruleus imaging overlaps with the Methods section in O'Callaghan et al. (2021). The study was approved by the Health Research Authority East of England - Cambridge Central Research Ethics Committee (REC 10/H0308/34), and all participants provided informed consent in accordance with the Declaration of Helsinki.

\section{PARTICIPANTS}

Eighteen people with idiopathic Parkinson's disease were recruited via the University of Cambridge Parkinson's disease research clinic and through Parkinson's UK volunteer panels. All participants met the United Kingdom Parkinson's Disease Society Brain Bank criteria, were aged between 50-80 years, and had no contraindications to 7T MRI or atomoxetine. No participants had dementia, based on the Movement Disorder Society criteria for Parkinson's disease dementia (Emre et al., 2007) and the mini-mental state examination (score > 26; Martinez-Martin et al., 2011). None had current impulse control disorders, based on clinical impression and the Questionnaire for ImpulsiveCompulsive Disorders in Parkinson's Disease (QUIP-Current Short) screening tool (Weintraub et al., 2009). Levodopa equivalent daily dose (LEDD) was calculated according to Tomlinson et al. (2010).

Twenty-one age-, sex- and education-matched healthy controls were recruited from local volunteer panels, to provide normative data. They had no history of neurological or psychiatric disorders, and were not using psychoactive medications.

One control participant and one participant with Parkinson's disease had excessive amounts of missing visuomotor task data ( $\geq 50 \%$ of trials) due to technical issues. After excluding these participants, the final sample consisted of 17 participants with Parkinson's disease and 20 controls. Demographic details and clinical characteristics are provided in Table 1 and the Supplementary Materials.

\section{STUdY PROCEDURE}

Participants with Parkinson's disease were tested across three sessions. The first session consisted of MRI scanning and clinical assessment, including the Movement Disorder Society Unified Parkinson's Disease Rating Scale (MDS-UPDRS; Goetz et al., 2008), mini-mental state examination 
medRxiv preprint doi: https://doi.org/10.1101/2021.07.04.21259922; this version posted July 6,2021 . The copyright holder for this preprint (which was not certified by peer review) is the author/funder, who has granted medRxiv a license to display the preprint in perpetuity.

It is made available under a CC-BY 4.0 International license .

(MMSE), Montreal cognitive assessment (MoCA; Nasreddine et al., 2005) and the revised Addenbrooke's cognitive examination (ACE-R; Mioshi et al., 2006).

The second and third sessions formed a double-blind randomised placebo-controlled crossover study, with $40 \mathrm{mg}$ of oral atomoxetine or placebo. The $40 \mathrm{mg}$ atomoxetine dose is widely used as a welltolerated 'starter dose' (Hinson et al., 2017; Weintraub et al., 2010) that is capable of modulating behaviour and brain function in Parkinson's disease (Kehagia et al., 2014; Rae et al., 2016; Z. Ye et al., 2015). The drug order was pseudorandomly permuted in blocks of six successive participants, to ensure that the order was balanced across the group. This means that three participants were pseudorandomly assigned to the placebo-atomoxetine order and three to the atomoxetine-placebo order within each block of the $1^{\text {st }}-6^{\text {th }}, 7^{\text {th }}-12^{\text {th }}$, and $13^{\text {th }}-18^{\text {th }}$ participants. The sessions were scheduled at least 6 days apart $(\mathrm{M}=7.29$ days, $\mathrm{SD}=1.76$ days, range: $6-14$ days $)$ and at a similar time of day. For each session, blood samples were taken two hours after drug administration, to coincide with predicted peak plasma concentration of atomoxetine after a single oral dose (Sauer et al., 2005). Mean plasma concentration (Teichert et al., 2020) was $264.07 \mathrm{ng} / \mathrm{mL}$ after atomoxetine $(\mathrm{SD}=124.50 \mathrm{ng} / \mathrm{mL}$, range: $90.92-595.11 \mathrm{ng} / \mathrm{mL})$ and $0 \mathrm{ng} / \mathrm{mL}$ after placebo. After the blood sample, participants completed an experimental task battery that included a visuomotor task, which is the focus of the current manuscript. Participants were on their regular anti-parkinsonian medications throughout the study.

Control participants were tested in a single session that included MRI scanning and the same experimental task battery as the participants with Parkinson's disease. The control group did not undergo the drug manipulation.

All participants completed a set of questionnaires that assessed mood and various behavioural symptoms. With the exception of the Apathy Scale (Starkstein et al., 1992), these questionnaires were primarily collected for demographic purposes, and are described in detail in the Supplementary Materials.

\section{VISUOMOTOR TASK}

We administered a visuomotor task (adapted from Hezemans et al. (2020)) that involved effortful, goal-directed behaviour, and required participants to estimate their own performance. For each trial, participants pressed on a force sensor for 3 seconds using the index finger of their dominant hand, to subsequently trigger a ballistic ball movement on the screen, aiming for the ball to stop on the target. The force response was defined as the mean force exerted from 2 to 2.5 seconds, divided by the 
medRxiv preprint doi: https://doi.org/10.1101/2021.07.04.21259922; this version posted July 6,2021 . The copyright holder for this preprint (which was not certified by peer review) is the author/funder, who has granted medRxiv a license to display the preprint in perpetuity.

It is made available under a CC-BY 4.0 International license .

participant's maximum force (estimated separately, see below). The ball's displacement from a fixed starting position towards the target increased monotonically with the force response. In other words, the relative force exerted on the sensor directly determined the ball's final position. As a measure of basic task performance, we calculated the force error, defined as the difference between the force response and the force required to stop the ball perfectly on target.

The task consisted of two types of trials: basic trials and estimation trials. For basic trials, participants viewed the outcome of their action - that is, the ball's full trajectory to its final position on the screen. The difference between the ball's final position and the target constituted the performance error, expressed in pixels.

\section{Estimating task performance}

For estimation trials, the ball's trajectory was not shown, and participants were asked to estimate where the ball would have stopped. Participants were shown a grid of 12 evenly spaced response options (labelled with numbers 1 to 12 ), where one of the response options was centred on the true final ball position (i.e. the veridical response option). Participants verbally indicated their belief about the ball's final location to the experimenter as a digit ("one" to "twelve"). The difference between the selected response option and the veridical response option constituted the estimation error. Note that the target was not shown during the estimation procedure, and participants did not receive feedback regarding the true final ball position on estimation trials.

For each estimation trial, the veridical response option was selected pseudorandomly from a uniform distribution between 3 and 10. This ensured that the absolute position of the estimation grid was not indicative of the true final ball position, and that there were sufficient response options both to the left and right of the true final ball position. The width of the estimation grid was $30 \%$ of the screen width. Note that in our previous work using an unconstrained (mouse cursor) estimation procedure (Hezemans et al., 2020), the standard deviation of estimation error was $6.80 \%$ of the screen width.

\section{Task procedure}

The task started with a practice block of 15 basic trials. In the last 5 of these practice trials, participants were asked to estimate their performance after observing the full ball trajectory, to introduce the estimation procedure. The experimenter verified that the participant understood the estimation procedure, and if necessary the practice block was repeated. The practice data was not analysed further. The subsequent test phase consisted of 4 blocks of 30 trials each. Each block consisted of 20 basic trials and 10 estimation trials. The trials within each block were pseudorandomly interleaved, with the constraints that the first 3 trials were always basic trials and 
medRxiv preprint doi: https://doi.org/10.1101/2021.07.04.21259922; this version posted July 6,2021 . The copyright holder for this preprint (which was not certified by peer review) is the author/funder, who has granted medRxiv a license to display the preprint in perpetuity.

It is made available under a CC-BY 4.0 International license .

that there could not be two consecutive estimation trials. In total, each testing session consisted of 120 trials, of which 40 were estimation trials. To minimise potential effects of fatigue on task performance, participants were given the opportunity to take a short break after each block.

For consistency with the original study design in Hezemans et al. (2020), the task additionally featured experimental manipulations of effort and reward. Effort was manipulated by displaying the target either relatively close to or far from the ball's starting position, corresponding to $35 \%$ or $65 \%$ of the participant's maximum force. Reward was manipulated by either giving participants points (tallied at the top of the screen) in relation to their performance on basic trials, or not giving any points. We used a $2 \times 2$ factorial design (low effort vs. high effort; no reward vs. reward) with one block of 30 trials for each combination of effort and reward. However, we did not analyse these factors further, following Hezemans et al. (2020).

\section{Maximum force calibration}

We established each participant's maximum force at the start of the task, so that the relative level of force required could be fixed across participants. Participants pressed with the maximum force they could sustain for 10 seconds. The mean force within a 5 second window with the lowest variance was taken as the response. This procedure was repeated three times, and the highest value across iterations was taken as the participant's maximum force.

\section{Bayesian Modelling of Performance Estimates}

The estimation trials in our visuomotor task can be considered as a Bayesian inference problem (Gregory, 1980; Knill \& Richards, 1996; Körding \& Wolpert, 2004; Pouget et al., 2013), where for each trial $n$ participants infer a hidden variable $x^{(n)}$ given noisy sensory evidence $s^{(n)}$ :

$$
\underbrace{p\left(x^{(n)} \mid S^{(n)}\right)}_{\text {posterior }} \propto \underbrace{p\left(S^{(n)} \mid x^{(n)}\right)}_{\text {likelihood }} \cdot \underbrace{p\left(x^{(n)}\right)}_{\text {prior }}
$$

The sensory evidence is assumed to be corrupted by additive Gaussian noise with variance $\sigma_{s}^{2}$, and the prior is assumed to follow a Gaussian distribution with mean $x_{0}^{(n)}$ and variance $\sigma_{0}^{2}$ :

$$
p\left(x^{(n)} \mid s^{(n)}\right) \propto \mathcal{N}\left(s^{(n)}, \sigma_{s}^{2}\right) \cdot \mathcal{N}\left(x_{0}^{(n)}, \sigma_{0}^{2}\right)
$$

The optimal estimate of the hidden variable, $\hat{x}^{(n)}$, minimises the expected loss $\mathcal{L}\left(\hat{x}^{(n)}, x^{(n)}\right)$ given the sensory evidence. Since the posterior distribution in Equation 5 is Gaussian, its mean, median, 
medRxiv preprint doi: https://doi.org/10.1101/2021.07.04.21259922; this version posted July 6, 2021. The copyright holder for this preprint (which was not certified by peer review) is the author/funder, who has granted medRxiv a license to display the preprint in perpetuity.

It is made available under a CC-BY 4.0 International license .

and mode have the same value. We can therefore assume without loss of generality that the optimal estimate equals the posterior mean (Xiang et al., 2021):

$$
\begin{aligned}
\hat{x}^{(n)} & =\underset{\hat{x}^{(n)}}{\operatorname{argmin}} \mathbb{E}\left[\mathcal{L}\left(\hat{x}^{(n)}, x^{(n)}\right) \mid s^{(n)}\right] \\
& =\frac{\sigma_{0}^{2}}{\sigma_{0}^{2}+\sigma_{s}^{2}} \cdot s^{(n)}+\frac{\sigma_{s}^{2}}{\sigma_{s}^{2}+\sigma_{0}^{2}} \cdot x_{0}^{(n)}
\end{aligned}
$$

\section{Estimating prior weighting}

In the current study, we assume that the sensory evidence is centred on the true final ball position $x_{\text {ball }}^{(n)}$ with variance $\sigma_{\text {evidence }}^{2}$, and the prior is centred on the target position $x_{\text {target }}^{(n)}$ with variance $\sigma_{\text {prior. }}^{2}$ The observed estimate of performance $x_{\text {estimate }}^{(n)}$ can then be modelled as the sum of $x_{\text {ball }}^{(n)}$ and $x_{\text {target }}^{(n)}$, weighted by their inverse variances:

$$
x_{\text {estimate }}^{(n)}=\frac{\sigma_{\text {prior }}^{2}}{\sigma_{\text {prior }}^{2}+\sigma_{\text {evidence }}^{2}} \cdot x_{\text {ball }}^{(n)}+\frac{\sigma_{\text {evidence }}^{2}}{\sigma_{\text {evidence }}^{2}+\sigma_{\text {prior }}^{2}} \cdot x_{\text {target }}^{(n)}
$$

The prior weighting term, $w_{\text {prior }}=\frac{\sigma_{\text {evidence }}^{2}}{\sigma_{\text {evidence }}^{2}+\sigma_{\text {prior }}^{2}}$, can be estimated as the negative of the regression coefficient of estimation error on performance error (Vilares \& Kording, 2017; Wolpe et al., 2014):

$$
\underbrace{x_{\text {estimate }}^{(n)}-x_{\text {ball }}^{(n)}}_{\text {estimation error }}=-w_{\text {prior }} \cdot \underbrace{\left(x_{\text {ball }}^{(n)}-x_{\text {target }}^{(n)}\right)}_{\text {performance error }}
$$

We used a linear mixed effects model to fit the linear relationship between estimation errors and performance errors, allowing the slope to vary for each of the 54 completed testing sessions (20 control participants plus 17 participants with Parkinson's disease tested twice). Prior to model fitting, the estimation errors and performance errors were z-scored for each testing session, to bring these variables onto a common scale and to ensure that the intercept was zero, as assumed by the model (Equation 3). We performed a parameter recovery analysis to ensure that this analysis procedure could reliably identify data-generating parameter values, given our experimental design and model assumptions (Supplementary Materials).

\section{Hierarchical Bayesian modelling of estimation trials}

The observed estimate of performance can alternatively be modelled probabilistically, as a sample from the full posterior distribution:

$$
x_{\text {estimate }}^{(n)} \sim \mathcal{N}\left(\hat{x}^{(n)}, \sigma_{\hat{x}}^{2}\right)
$$


medRxiv preprint doi: https://doi.org/10.1101/2021.07.04.21259922; this version posted July 6, 2021. The copyright holder for this preprint (which was not certified by peer review) is the author/funder, who has granted medRxiv a license to display the preprint in perpetuity.

where the posterior variance $\sigma_{\widehat{x}}^{2}$ is given by:

$$
\sigma_{\hat{x}}^{2}=\frac{\sigma_{\text {evidence }}^{2} \cdot \sigma_{\text {prior }}^{2}}{\sigma_{\text {evidence }}^{2}+\sigma_{\text {prior }}^{2}}
$$

By explicitly modelling the posterior variance, the prior and sensory evidence variances can be separately identified. For example, although an increase in prior variance or a decrease in sensory evidence variance could have the same effect on prior weighting (Equation 2), these changes would have dissociable effects on the posterior variance (Equation 8).

Potential drug effects on the prior and sensory evidence variances were modelled as atomoxetineinduced changes $(\Delta)$ in these parameters, relative to the placebo session. For example, the standard deviation of the prior for participant $i$ in session $j$ was defined as follows:

$$
\sigma_{\text {prior }}^{(i, j)}= \begin{cases}\sigma_{\text {prior }}^{(i)} & \text { if } j=\text { placebo } \\ \sigma_{\text {prior }}^{(i)}+\Delta_{\text {prior }}^{(i)} & \text { if } j=\text { atomoxetine }\end{cases}
$$

We additionally accounted for any consistent spatial shifts in the sensory evidence, $x_{\text {shift }}$, to relax the assumption that the trial-wise sensory evidence distribution was centred on the true final ball position (Hezemans et al., 2020; Wolpe et al., 2014, 2015):

$$
x_{\text {evidence }}^{(n)}=x_{\text {ball }}^{(n)}+x_{\text {shift }}
$$

The model consisted of five free parameters in total: $\sigma_{\text {prior }}, \sigma_{\text {evidence }}, \Delta_{\text {prior }}, \Delta_{\text {evidence }}$, and $x_{\text {shift }}$. We estimated these parameters hierarchically, such that parameters for a given participant $i$ were sampled from corresponding group-level distributions:

$$
\begin{gathered}
\sigma_{\text {prior }}^{(i)} \sim \mathcal{N}_{+}\left(\mu_{\sigma_{\text {prior }},}\left(\sigma_{\sigma_{\text {prior }}}\right)^{2}\right) \\
\sigma_{\text {evidence }}^{(i)} \sim \mathcal{N}_{+}\left(\mu_{\sigma_{\text {evidence }}}\left(\sigma_{\sigma_{\text {evidence }}}\right)^{2}\right) \\
\Delta_{\text {prior }}^{(i)} \sim \mathcal{N}\left(\mu_{\Delta_{\text {prior }},}\left(\sigma_{\Delta_{\text {prior }}}\right)^{2}\right) \\
\Delta_{\text {evidence }}^{(i)} \sim \mathcal{N}\left(\mu_{\Delta_{\text {evidence }}},\left(\sigma_{\Delta_{\text {evidence }}}\right)^{2}\right) \\
x_{\text {shift }}^{(i)} \sim \mathcal{N}\left(\mu_{x_{\text {shift }}}\left(\sigma_{x_{\text {shift }}}\right)^{2}\right)
\end{gathered}
$$

where $\mathcal{N}_{+}$denotes a Gaussian distribution that is truncated to only allow positive values. We generally assigned relatively broad ("weakly informative") prior distributions on the group-level means and 
medRxiv preprint doi: https://doi.org/10.1101/2021.07.04.21259922; this version posted July $6,2021$. The copyright holder for this preprint (which was not certified by peer review) is the author/funder, who has granted medRxiv a license to display the preprint in perpetuity. It is made available under a CC-BY 4.0 International license .

variances of the model parameters. The priors on $\mu_{\Delta_{\text {prior }}}, \mu_{\Delta_{\text {evidence }}}$, and $\mu_{x_{\text {shift }}}$ were all centred on zero - that is, we conservatively assumed a priori that on average there would be no drug effects or spatial shift. Further details about the model specification are provided in the Supplementary Materials. Our primary interest was in the participant-level estimates of drug effects on the standard deviation of the prior and sensory evidence distributions.

We additionally fit three variants of this model, where the prior and / or sensory evidence standard deviation parameters were constrained to be fixed across the placebo and atomoxetine sessions. Specifically, one model variant only allowed for drug effects on the prior standard deviation, another model variant only allowed for drug effects on sensory evidence standard deviation, and a final model variant did not include any drug-induced change parameters. However, a comparison of each model's estimated pointwise predictive accuracy (Vehtari et al., 2017) favoured the inclusion of drug effects on both the prior and sensory evidence standard deviations (Supplementary Materials), and we therefore focused on the parameter estimates from the 'full' model.

We used Markov Chain Monte Carlo (MCMC) sampling to estimate the posterior distributions of the model parameters. We used 8 chains with 4000 samples each, and discarded the first 2000 samples of each chain as the warm-up. Model convergence was confirmed by the potential scale reduction statistic $\hat{R}(<1.004$ for all parameters), and by visual inspection of the time-series plots of the MCMC samples. The model's goodness of fit was assessed by visually comparing the observed data to simulated data generated from the model's posterior predictive distribution (Supplementary Materials). For a given parameter of interest, we took the median of its posterior distribution as the optimal estimate.

\section{MRI ACQUISITION}

The MR images were acquired with a 7T Magnetom Terra (Siemens, Erlangen, Germany), using a 32-channel head coil (Nova Medical, Wilmington, USA). The locus coeruleus was imaged using a 3D magnetisation transfer (MT) weighted sequence at high resolution (Priovoulos et al., 2018; R. Ye et al., 2021). The sequence included 112 oblique, axial slices oriented perpendicular to the long axis of the brainstem, to cover both the midbrain and the pontine regions. A train of 20 Gaussian-shaped RF pulses was applied at $6.72 \mathrm{ppm}$ off resonance, $420^{\circ}$ flip angle, followed by a turbo-flash readout $\left(\mathrm{TE}=4.08 \mathrm{~ms}, \mathrm{TR}=1251 \mathrm{~ms}\right.$, flip-angle $=8^{\circ}$, voxel size $=0.4 \times 0.4 \times 0.5 \mathrm{~mm}^{3}, 6 / 8$ phase and slice partial Fourier, bandwidth $=140 \mathrm{~Hz} / \mathrm{px}$, no acceleration, 14.3\%- oversampling, TA $\sim 7 \mathrm{~min})$. The transmit voltage was adjusted for each participant based on the average flip angle in the central area of the pons, which was obtained from a B1 pre-calibration scan. The MT scan was repeated twice 
medRxiv preprint doi: https://doi.org/10.1101/2021.07.04.21259922; this version posted July 6,2021 . The copyright holder for this preprint (which was not certified by peer review) is the author/funder, who has granted medRxiv a license to display the preprint in perpetuity.

It is made available under a CC-BY 4.0 International license .

and averaged offline to enhance the signal-to-noise ratio. An additional scan was acquired with the same parameters as above but without the off-resonance pulses. For anatomical coregistration, a high resolution T1-weighted structural image $(0.7 \mathrm{~mm}$ isotropic) was acquired using the MP2RAGE sequence with the UK7T Network harmonised protocol: TE $=2.58 \mathrm{~ms}$, TR $=3500 \mathrm{~ms}, \mathrm{BW}=300$ $\mathrm{Hz} / \mathrm{px}$, voxel size $=0.7 \times 0.7 \times 0.7 \mathrm{~mm}^{3}, \mathrm{FoV}=224 \times 224 \times 157 \mathrm{~mm}^{3}$, acceleration factor $(\mathrm{A}>>\mathrm{P})=$ 3 , flip angles $=5 / 2^{\circ}$ and inversion times $(\mathrm{TI})=725 / 2150 \mathrm{~ms}$ for the first $/$ second images.

\section{IMAge Processing ANd LoCuS COERULeUs INTEGRITY}

The image processing pipeline is described in detail in O'Callaghan et al. (2021), which used an identical pipeline as the current study (based on Ye et al. (2021)). The MT images were bias field corrected, and then entered into a T1-driven coregistration pipeline to warp the images to the isotropic $0.5 \mathrm{~mm}$ ICBM152 (International Consortium for Brain Mapping) T1-weighted asymmetric template (Fonov et al., 2011).

The co-registered MT images were used to quantify the contrast with respect to a reference region, the central pontine tegmentum, generating contrast-to-noise ratio (CNR) maps. For each participant $i$ and voxel $j$, the signal $x^{(i, j)}$ was contrasted with the mean reference signal $\mu_{\mathrm{ref}}^{(i)}$, and then divided by the standard deviation of the reference signal $\sigma_{\text {ref }}^{(i)}$ :

$$
\mathrm{CNR}^{(i, j)}=\frac{x^{(i, j)}-\mu_{\mathrm{ref}}^{(i)}}{\sigma_{\mathrm{ref}}^{(i)}}
$$

To ensure that the CNR values were localised to the locus coeruleus, we used an independent locus coeruleus atlas based on a separate sample of 29 age- and education-matched healthy controls (O'Callaghan et al., 2021). For each axial slice on the rostrocaudal extent, the locations of the left and right locus coeruleus were determined using a semi-automated segmentation method (R. Ye et al., 2021). The locus coeruleus voxels were segmented into binary images, and then averaged and thresholded at $5 \%$ to obtain a template ( 705 voxels, $88.125 \mathrm{~mm}^{3}$; see Supplementary Figure 1 in O’Callaghan et al. (2021)).

To estimate the locus coeruleus integrity, we applied the independent locus coeruleus atlas to each participant's CNR map, and then calculated the mean CNR value across the whole structure. We also performed this calculation after applying a more stringent locus coeruleus atlas that was thresholded at $25 \%$ (274 voxels, $\left.34.25 \mathrm{~mm}^{3}\right)$. In addition, we performed an alternative calculation of locus coeruleus contrast that replaced the denominator in Equation 12 with the mean reference signal: 
medRxiv preprint doi: https://doi.org/10.1101/2021.07.04.21259922; this version posted July 6,2021 . The copyright holder for this preprint (which was not certified by peer review) is the author/funder, who has granted medRxiv a license to display the preprint in perpetuity.

$\mathrm{CR}^{(i, j)}=\left(x^{(i, j)}-\mu_{\text {ref }}^{(i)}\right) / \mu_{\text {ref }}^{(i)}$, yielding a contrast ratio rather than contrast-to-noise ratio. However, as described in the Results section, these alternative contrast methods did not meaningfully change the relationship between locus coeruleus integrity and the atomoxetine-induced change in prior weighting.

We used an analogous approach to obtain CNR from the substantia nigra, as a neuromelanin-rich control region. This analysis pipeline is described in detail in the Supplementary Materials in O'Callaghan et al. (2021) and in Rua et al. (2021). In brief, the MT images from the separate sample of 29 age- and education-matched healthy controls were used to create an independent probabilistic atlas of the substantia nigra, thresholded at $5 \%$. This atlas was then applied to the current study sample to compute a CNR map (Equation 12), where the reference region was defined as the midbrain background (crus cerebri). The mean CNR value for each participant served as the estimate of substantia nigra CNR.

\section{STATISTICAL INFERENCE}

We report both frequentist and Bayes factor (BF) analyses for hypothesis testing, with a significance threshold of $p=.05$ (two-sided) for frequentist analyses. We present the BF for the alternative hypothesis over the null hypothesis (i.e., $\mathrm{BF}_{10}$ ), such that $\mathrm{BF}>3$ indicates "positive evidence" for the alternative hypothesis (Kass \& Raftery, 1995). All BF analyses used the default 'JZS' prior on the effect size under the alternative hypothesis (Rouder et al., 2009, 2012). To obtain BFs for specific effects in ANOVAs and linear (mixed) models, we used Bayesian model averaging to estimate the change from prior to posterior inclusion odds ("inclusion BF"). This BF indicates how much more likely the data are when a given effect is included in the model, compared to when the effect is excluded (Hinne et al., 2020). The $p$-values for fixed effects in linear mixed models were obtained using the Kenward-Roger approximation (Singmann \& Kellen, 2019). Prior to analyses, we z-scored all continuous variables, and assigned sum-to-zero contrasts to categorical variables. For linear models, the residuals were assumed to be normally distributed and to have constant variance, but these assumptions were not formally tested. The reported $p$-values are uncorrected for multiple comparisons.

\section{SOFTWARE AND EQUIPMENT}

The visuomotor task was implemented in MATLAB R2018b using the Psychophysics Toolbox extensions (version 3; Brainard, 1997; Kleiner et al., 2007; Pelli, 1997), and was displayed on a 12.5inch laptop screen $(1920 \times 1080$ pixels $)$. The force sensor had a sampling rate of $60 \mathrm{~Hz}$ and a 
medRxiv preprint doi: https://doi.org/10.1101/2021.07.04.21259922; this version posted July 6,2021 . The copyright holder for this preprint (which was not certified by peer review) is the author/funder, who has granted medRxiv a license to display the preprint in perpetuity.

It is made available under a CC-BY 4.0 International license.

measurement accuracy of $\pm 9.8 \mathrm{mN}$. All statistical analyses were implemented in $\mathrm{R}$ (version 3.6.1; R Core Team, 2019), using the 'tidyverse' (Wickham et al., 2019) and 'tidybayes' (Kay, 2020) packages for data organisation and visualisation, the 'afex' (Singmann et al., 2020) package for ANOVA and linear mixed model fitting, the 'emmeans' (Lenth et al., 2020) and 'interactions' (Long, 2019) packages for post-hoc analyses, and the 'BayesFactor' (Morey et al., 2018) and 'bayestestR' (Makowski et al., 2019) packages for Bayes Factor analysis. The hierarchical Bayesian modelling was implemented in Stan (Carpenter et al., 2017) using the 'rstan' (Stan Development Team, 2019) interface package. The magnetisation transfer images were processed using the Advanced Normalization Tools (ANTS, version 2.2.0; Tustison et al., 2014) and in-house MATLAB scripts (O'Callaghan et al., 2021; R. Ye et al., 2021). 
medRxiv preprint doi: https://doi.org/10.1101/2021.07.04.21259922; this version posted July 6, 2021. The copyright holder for this preprint (which was not certified by peer review) is the author/funder, who has granted medRxiv a license to display the preprint in perpetuity.

\section{ACKNOWLEDGMENTS}

We thank the volunteers for their participation, staff at the Wolfson Brain Imaging Centre and National Institute for Health Research (NIHR) Cambridge Clinical Research Facility for their help with data collection, and members of the Cambridge Centre for Frontotemporal Dementia and Related Disorders for valuable suggestions and discussions. The study was funded by the UK Medical Research Council (SUAG/051 G101400); the Wellcome Trust (220258); Parkinson's UK (K-1702); the Cambridge Centre for Parkinson-Plus (RG95450); the James S McDonnell Foundation (21 ${ }^{\text {st }}$ Century Science: Understanding Human Cognition); the NIHR Clinical Research Facility and Cambridge Biomedical Research Centre (BRC-1215-20014); a Cambridge Trust Vice-Chancellor's Award and Fitzwilliam College scholarship; an NIHR Academic Clinical Fellowship; a Neil Hamilton Fairley Fellowship from the Australian Mental Health and Medical Research Council (GNT1091310); the Holt Fellowship (RG86564); the Association of British Neurologists, Patrick Berthoud Charitable Trust (RG99368); the British Academy (PF160048); the Guarantors of Brain (101149); and an RCUK/UKRI Research Innovation Fellowship awarded by the UK Medical Research Council (MR/R007446/1). The views expressed are those of the authors and not necessarily those of the NIHR or the Department of Health and Social Care. For the purpose of open access, the authors have applied a CC BY public copyright licence to any Author Accepted Manuscript version arising from this submission.

\section{Data AVAilability Statement}

De-identified behavioural data and summary imaging metrics are freely available through the Open Science Framework [OSF link to be added].

\section{Code AVAILABILITy Statement}

Code to reproduce statistical analyses, computational modelling and manuscript figures is freely available through the Open Science Framework [OSF link to be added]. 
medRxiv preprint doi: https://doi.org/10.1101/2021.07.04.21259922; this version posted July 6 , 2021. The copyright holder for this preprint (which was not certified by peer review) is the author/funder, who has granted medRxiv a license to display the preprint in perpetuity.

\section{REFERENCES}

Adams, R. A., Shipp, S., \& Friston, K. J. (2013). Predictions not commands: Active inference in the motor system. Brain Structure and Function, 218(3), 611-643. https://doi.org/10.1007/s00429-012-0475-5

Arnsten, A. F. T., \& Goldman-Rakic, P. S. (1984). Selective prefrontal cortical projections to the region of the locus coeruleus and raphe nuclei in the rhesus monkey. Brain Research, 306(1-2), 9-18. https://doi.org/10.1016/0006-8993(84)90351-2

Aston-Jones, G., \& Cohen, J. D. (2005). An integrative theory of locus coeruleus-norepinephrine function: Adaptive Gain and Optimal Performance. Annual Review of Neuroscience, 28(1), 403-450. https://doi.org/10.1146/annurev.neuro.28.061604.135709

Azulay, J.-P., Mesure, S., Amblard, B., Blin, O., Sangla, I., \& Pouget, J. (1999). Visual control of locomotion in Parkinson's disease. Brain, 122(1), 111-120. https://doi.org/10.1093/brain/122.1.111

Bari, A., \& Aston-Jones, G. (2013). Atomoxetine modulates spontaneous and sensory-evoked discharge of locus coeruleus noradrenergic neurons. Neuropharmacology, 64(c), 53-64. https://doi.org/10.1016/j.neuropharm.2012.07.020

Bauer, D. J., \& Curran, P. J. (2005). Probing Interactions in Fixed and Multilevel Regression: Inferential and Graphical Techniques. Multivariate Behavioral Research, 40(3), 373-400. https://doi.org/10.1207/s15327906mbr4003_5

Behrens, T. E. J., Woolrich, M. W., Walton, M. E., \& Rushworth, M. F. S. (2007). Learning the value of information in an uncertain world. Nature Neuroscience, 10(9), 1214-1221. https://doi.org/10.1038/nn1954

Berridge, C. W., \& Waterhouse, B. D. (2003). The locus coeruleus-noradrenergic system: Modulation of behavioral state and state-dependent cognitive processes. Brain Research Reviews, 42(1), 33-84. https://doi.org/10.1016/S0165-0173(03)00143-7

Bouret, S., \& Richmond, B. J. (2015). Sensitivity of Locus Ceruleus Neurons to Reward Value for GoalDirected Actions. Journal of Neuroscience, 35(9), 4005-4014. https://doi.org/10.1523/JNEUROSCI.4553-14.2015

Bouret, S., \& Sara, S. J. (2005). Network reset: A simplified overarching theory of locus coeruleus noradrenaline function. Trends in Neurosciences, 28(11), 574-582. https://doi.org/10.1016/j.tins.2005.09.002

Brainard, D. H. (1997). The Psychophysics Toolbox. Spatial Vision, 10(4), 433-436. https://doi.org/10.1163/156856897X00357

Brown, H. R., Adams, R. A., Parees, I., Edwards, M., \& Friston, K. J. (2013). Active inference, sensory attenuation and illusions. Cognitive Processing, 14(4), 411-427. https://doi.org/10.1007/s10339-0130571-3

Bymaster, F. P., Katner, J. S., Nelson, D. L., Hemrick-Luecke, S. K., Threlkeld, P. G., Heiligenstein, J. H., Morin, S. M., Gehlert, D. R., \& Perry, K. W. (2002). Atomoxetine increases extracellular levels of norepinephrine and dopamine in prefrontal cortex of rat: A potential mechanism for efficacy in attention deficit/hyperactivity disorder. Neuropsychopharmacology, 27(5), 699-711. https://doi.org/10.1016/S0893-133X(02)00346-9

Carpenter, B., Gelman, A., Hoffman, M. D., Lee, D., Goodrich, B., Betancourt, M., Brubaker, M., Guo, J., Li, P., \& Riddell, A. (2017). Stan: A Probabilistic Programming Language. Journal of Statistical Software, 76(1). https://doi.org/10.18637/jss.v076.i01

Cash, R., Dennis, T., L’Heureux, R., Raisman, R., Javoy-Agid, F., \& Scatton, B. (1987). Parkinson's disease and dementia: Norepinephrine and dopamine in locus ceruleus. Neurology, 37(1), 42-42. https://doi.org/10.1212/WNL.37.1.42 
medRxiv preprint doi: https://doi.org/10.1101/2021.07.04.21259922; this version posted July 6 , 2021. The copyright holder for this preprint (which was not certified by peer review) is the author/funder, who has granted medRxiv a license to display the preprint in perpetuity. It is made available under a CC-BY 4.0 International license .

Chong, T. T.-J., Bonnelle, V., Manohar, S., Veromann, K.-R., Muhammed, K., Tofaris, G. K., Hu, M., \& Husain, M. (2015). Dopamine enhances willingness to exert effort for reward in Parkinson's disease. Cortex, 69, 40-46. https://doi.org/10.1016/j.cortex.2015.04.003

Chong, T. T.-J., \& Husain, M. (2016). Chapter 17-The role of dopamine in the pathophysiology and treatment of apathy. In B. Studer \& S. Knecht (Eds.), Progress in Brain Research (Vol. 229, pp. 389 426). Elsevier. https://doi.org/10.1016/bs.pbr.2016.05.007

Chow, T. W., Binns, M. A., Cummings, J. L., Lam, I., Black, S. E., Miller, B. L., Freedman, M., Stuss, D. T., \& van Reekum, R. (2009). Apathy Symptom Profile and Behavioral Associations in Frontotemporal Dementia vs Dementia of Alzheimer Type. Archives of Neurology, 66(7), 888-893. https://doi.org/10.1001/archneurol.2009.92

Conte, A., Khan, N., Defazio, G., Rothwell, J. C., \& Berardelli, A. (2013). Pathophysiology of somatosensory abnormalities in Parkinson disease. Nature Reviews Neurology, 9(12), 687-697. https://doi.org/10.1038/nrneurol.2013.224

Cools, R. (2019). Chemistry of the Adaptive Mind: Lessons from Dopamine. Neuron, 104(1), 113-131. https://doi.org/10.1016/j.neuron.2019.09.035

Cools, R., \& D’Esposito, M. (2011). Inverted-U-Shaped Dopamine Actions on Human Working Memory and Cognitive Control. Biological Psychiatry, 69(12), e113-e125. https://doi.org/10.1016/j.biopsych.2011.03.028

Dabney, W., Kurth-Nelson, Z., Uchida, N., Starkweather, C. K., Hassabis, D., Munos, R., \& Botvinick, M. (2020). A distributional code for value in dopamine-based reinforcement learning. Nature, 577(7792), 671-675. https://doi.org/10.1038/s41586-019-1924-6

Dayan, P., \& Yu, A. J. (2006). Phasic norepinephrine: A neural interrupt signal for unexpected events. Network: Computation in Neural Systems, 17(4), 335-350. https://doi.org/10.1080/09548980601004024

den Brok, M. G. H. E., van Dalen, J. W., van Gool, W. A., van Charante, E. P. M., de Bie, R. M. A., \& Richard, E. (2015). Apathy in Parkinson's disease: A systematic review and meta-analysis. Movement Disorders, 30(6), 759-769. https://doi.org/10.1002/mds.26208

Devoto, P., Flore, G., Pani, L., \& Gessa, G. L. (2001). Evidence for co-release of noradrenaline and dopamine from noradrenergic neurons in the cerebral cortex. Molecular Psychiatry, 6(6), 657-664. https://doi.org/10.1038/sj.mp.4000904

Devoto, P., Flore, G., Saba, P., Fa, M., \& Gessa, G. L. (2005). Stimulation of the locus coeruleus elicits noradrenaline and dopamine release in the medial prefrontal and parietal cortex. Journal of Neurochemistry, 92(2), 368-374. https://doi.org/10.1111/j.1471-4159.2004.02866.x

Drew, D. S., Muhammed, K., Baig, F., Kelly, M., Saleh, Y., Sarangmat, N., Okai, D., Hu, M., Manohar, S., \& Husain, M. (2020). Dopamine and reward hypersensitivity in Parkinson's disease with impulse control disorder. Brain, 143(8), 2502-2518. https://doi.org/10.1093/brain/awaa198

Eldar, E., Cohen, J. D., \& Niv, Y. (2013). The effects of neural gain on attention and learning. Nature Neuroscience, 16(8), 1146-1153. https://doi.org/10.1038/nn.3428

Emre, M., Aarsland, D., Brown, R. G., Burn, D. J., Duyckaerts, C., Mizuno, Y., Broe, G. A., Cummings, J., Dickson, D. W., Gauthier, S., Goldman, J., Goetz, C., Korczyn, A., Lees, A., Levy, R., Litvan, I., McKeith, I., Olanow, W., Poewe, W., ... Dubois, B. (2007). Clinical diagnostic criteria for dementia associated with Parkinson's disease. Movement Disorders, 22(12), 1689-1707. https://doi.org/10.1002/mds.21507

Fonov, V., Evans, A. C., Botteron, K., Almli, C. R., McKinstry, R. C., \& Collins, D. L. (2011). Unbiased average age-appropriate atlases for pediatric studies. NeuroImage, 54(1), 313-327. https://doi.org/10.1016/j.neuroimage.2010.07.033

Friston, K. J. (2010). The free-energy principle: A unified brain theory? Nature Reviews Neuroscience, 11(2), 127-138. https://doi.org/10.1038/nrn2787 
medRxiv preprint doi: https://doi.org/10.1101/2021.07.04.21259922; this version posted July 6 , 2021. The copyright holder for this preprint (which was not certified by peer review) is the author/funder, who has granted medRxiv a license to display the preprint in perpetuity.

It is made available under a CC-BY 4.0 International license .

Friston, K. J., Daunizeau, J., Kilner, J., \& Kiebel, S. J. (2010). Action and behavior: A free-energy formulation. Biological Cybernetics, 102(3), 227-260. https://doi.org/10.1007/s00422-010-0364-z

Friston, K. J., FitzGerald, T., Rigoli, F., Schwartenbeck, P., \& Pezzulo, G. (2016). Active Inference: A Process Theory. Neural Computation, 29(1), 1-49. https://doi.org/10.1162/NECO_a_00912

Friston, K. J., Schwartenbeck, P., FitzGerald, T., Moutoussis, M., Behrens, T., \& Dolan, R. J. (2014). The anatomy of choice: Dopamine and decision-making. Philosophical Transactions of the Royal Society B: Biological Sciences, 369(1655), 20130481-20130481. https://doi.org/10.1098/rstb.2013.0481

Friston, K. J., Shiner, T., FitzGerald, T., Galea, J. M., Adams, R. A., Brown, H. R., Dolan, R. J., Moran, R. J., Stephan, K. E., \& Bestmann, S. (2012). Dopamine, Affordance and Active Inference. PLOS Computational Biology, 8(1), e1002327. https://doi.org/10.1371/journal.pcbi.1002327

Gilzenrat, M. S., Nieuwenhuis, S., Jepma, M., \& Cohen, J. D. (2010). Pupil diameter tracks changes in control state predicted by the adaptive gain theory of locus coeruleus function. Cognitive, Affective, \& Behavioral Neuroscience, 10(2), 252-269. https://doi.org/10.3758/CABN.10.2.252

Goetz, C. G., Tilley, B. C., Shaftman, S. R., Stebbins, G. T., Fahn, S., Martinez-Martin, P., Poewe, W., Sampaio, C., Stern, M. B., Dodel, R., Dubois, B., Holloway, R., Jankovic, J., Kulisevsky, J., Lang, A. E., Lees, A., Leurgans, S., LeWitt, P. A., Nyenhuis, D., ... LaPelle, N. (2008). Movement Disorder Society-sponsored revision of the Unified Parkinson's Disease Rating Scale (MDS-UPDRS): Scale presentation and clinimetric testing results. Movement Disorders, 23(15), 2129-2170. https://doi.org/10.1002/mds.22340

Gregory, R. L. (1980). Perceptions as hypotheses. Philosophical Transactions of the Royal Society of London. B, Biological Sciences, 290(1038), 181-197. https://doi.org/10.1098/rstb.1980.0090

Hauser, T. U., Allen, M., Purg, N., Moutoussis, M., Rees, G., \& Dolan, R. J. (2017). Noradrenaline blockade specifically enhances metacognitive performance. ELife, 6, e24901.

https://doi.org/10.7554/eLife.24901

Hawkes, C. H., Del Tredici, K., \& Braak, H. (2010). A timeline for Parkinson's disease. Parkinsonism \& Related Disorders, 16(2), 79-84. https://doi.org/10.1016/j.parkreldis.2009.08.007

Hezemans, F. H., Wolpe, N., \& Rowe, J. B. (2020). Apathy is associated with reduced precision of prior beliefs about action outcomes. Journal of Experimental Psychology: General. https://doi.org/10.1037/xge0000739

Hinne, M., Gronau, Q. F., van den Bergh, D., \& Wagenmakers, E.-J. (2020). A Conceptual Introduction to Bayesian Model Averaging. Advances in Methods and Practices in Psychological Science, 2515245919898657. https://doi.org/10.1177/2515245919898657

Hinson, V. K., Delambo, A., Elm, J., \& Turner, T. (2017). A Randomized Clinical Trial of Atomoxetine for Mild Cognitive Impairment in Parkinson's Disease. Movement Disorders Clinical Practice, 4(3), 416-423. https://doi.org/10.1002/mdc3.12455

Holland, N., Robbins, T. W., \& Rowe, J. B. (2021). The role of noradrenaline in cognition and cognitive disorders. Brain. https://doi.org/10.17863/CAM.65034

Jahn, C. I., Varazzani, C., Sallet, J., Walton, M. E., \& Bouret, S. (2020). Noradrenergic But Not Dopaminergic Neurons Signal Task State Changes and Predict Reengagement After a Failure. Cerebral Cortex. https://doi.org/10.1093/cercor/bhaa089

Jepma, M., Brown, S. B. R. E., Murphy, P. R., Koelewijn, S. C., de Vries, B., van den Maagdenberg, A. M., \& Nieuwenhuis, S. (2018). Noradrenergic and Cholinergic Modulation of Belief Updating. Journal of Cognitive Neuroscience, 30(12), 1803-1820. https://doi.org/10.1162/jocn_a_01317

Jepma, M., Murphy, P. R., Nassar, M. R., Rangel-Gomez, M., Meeter, M., \& Nieuwenhuis, S. (2016). Catecholaminergic Regulation of Learning Rate in a Dynamic Environment. PLOS Computational Biology, 12(10), e1005171. https://doi.org/10.1371/journal.pcbi.1005171 
medRxiv preprint doi: https://doi.org/10.1101/2021.07.04.21259922; this version posted July 6 , 2021. The copyright holder for this preprint (which was not certified by peer review) is the author/funder, who has granted medRxiv a license to display the preprint in perpetuity.

It is made available under a CC-BY 4.0 International license .

Jepma, M., \& Nieuwenhuis, S. (2011). Pupil Diameter Predicts Changes in the Exploration-Exploitation Trade-off: Evidence for the Adaptive Gain Theory. Journal of Cognitive Neuroscience, 23(7), 15871596. https://doi.org/10.1162/jocn.2010.21548

Jocham, G., Neumann, J., Klein, T. A., Danielmeier, C., \& Ullsperger, M. (2009). Adaptive Coding of Action Values in the Human Rostral Cingulate Zone. Journal of Neuroscience, 29(23), 7489-7496. https://doi.org/10.1523/JNEUROSCI.0349-09.2009

Joshi, S., \& Gold, J. I. (2020). Pupil Size as a Window on Neural Substrates of Cognition. Trends in Cognitive Sciences, 24(6), 466-480. https://doi.org/10.1016/j.tics.2020.03.005

Joshi, S., Li, Y., Kalwani, R. M., \& Gold, J. I. (2016). Relationships between Pupil Diameter and Neuronal Activity in the Locus Coeruleus, Colliculi, and Cingulate Cortex. Neuron, 89(1), 221-234. https://doi.org/10.1016/j.neuron.2015.11.028

Kass, R. E., \& Raftery, A. E. (1995). Bayes Factors. Journal of the American Statistical Association, 90(430), 773-795. https://doi.org/10.1080/01621459.1995.10476572

Kay, M. (2020). tidybayes: Tidy Data and Geoms for Bayesian Models. Zenodo. https://zenodo.org/record/3740308\#.XutG2WozbEY

Kehagia, A. A., Housden, C. R., Regenthal, R., Barker, R. A., Müller, U., Rowe, J., Sahakian, B. J., \& Robbins, T. W. (2014). Targeting impulsivity in Parkinson's disease using atomoxetine. Brain, 137(7), 1986-1997. https://doi.org/10.1093/brain/awu117

Kelly, C., \& Price, T. D. (2005). Correcting for Regression to the Mean in Behavior and Ecology. The American Naturalist, 166(6), 700-707. https://doi.org/10.1086/497402

Kleiner, M., Brainard, D., \& Pelli, D. (2007). What's new in Psychtoolbox-3? 30th European Conference on Visual Perception.

Klockgether, T., \& Dichgans, J. (1994). Visual control of arm movement in Parkinson's disease. Movement Disorders, 9(1), 48-56. https://doi.org/10.1002/mds.870090108

Knill, D. C., \& Richards, W. (Eds.). (1996). Perception as Bayesian Inference. Cambridge University Press.

Koller, M. (2016). robustlmm: An R Package for Robust Estimation of Linear Mixed-Effects Models. Journal of Statistical Software, 75(6). https://doi.org/10.18637/jss.v075.i06

Konczak, J., Sciutti, A., Avanzino, L., Squeri, V., Gori, M., Masia, L., Abbruzzese, G., \& Sandini, G. (2012). Parkinson's disease accelerates age-related decline in haptic perception by altering somatosensory integration. Brain, 135(11), 3371-3379. https://doi.org/10.1093/brain/aws265

Körding, K. P., \& Wolpert, D. M. (2004). Bayesian integration in sensorimotor learning. Nature, 427(6971), 244-247. https://doi.org/10.1038/nature02169

Krishnamurthy, K., Nassar, M. R., Sarode, S., \& Gold, J. I. (2017). Arousal-related adjustments of perceptual biases optimize perception in dynamic environments. Nature Human Behaviour, 1(6), 1-11. https://doi.org/10.1038/s41562-017-0107

Lanctôt, K. L., Agüera-Ortiz, L., Brodaty, H., Francis, P. T., Geda, Y. E., Ismail, Z., Marshall, G. A., Mortby, M. E., Onyike, C. U., Padala, P. R., Politis, A. M., Rosenberg, P. B., Siegel, E., Sultzer, D. L., \& Abraham, E. H. (2017). Apathy associated with neurocognitive disorders: Recent progress and future directions. Alzheimer's \& Dementia, 13(1), 84-100. https://doi.org/10.1016/j.jalz.2016.05.008

Lansdall, C. J., Coyle-Gilchrist, I. T. S., Jones, P. S., Rodríguez, P. V., Wilcox, A., Wehmann, E., Dick, K. M., Robbins, T. W., \& Rowe, J. B. (2017). Apathy and impulsivity in frontotemporal lobar degeneration syndromes. Brain, 140(6), 1792-1807. https://doi.org/10.1093/brain/awx101

Lansdall, C. J., Coyle-Gilchrist, I. T. S., Vázquez Rodríguez, P., Wilcox, A., Wehmann, E., Robbins, T. W., \& Rowe, J. B. (2019). Prognostic importance of apathy in syndromes associated with frontotemporal lobar degeneration. Neurology, 92(14), e1547-e1557.

https://doi.org/10.1212/WNL.0000000000007249 
medRxiv preprint doi: https://doi.org/10.1101/2021.07.04.21259922; this version posted July 6,2021 . The copyright holder for this preprint (which was not certified by peer review) is the author/funder, who has granted medRxiv a license to display the preprint in perpetuity. It is made available under a CC-BY 4.0 International license .

Lawson, R. P., Bisby, J., Nord, C. L., Burgess, N., \& Rees, G. (2021). The Computational, Pharmacological, and Physiological Determinants of Sensory Learning under Uncertainty. Current Biology, 31(1), 163172.e4. https://doi.org/10.1016/j.cub.2020.10.043

Le Bouc, R., Rigoux, L., Schmidt, L., Degos, B., Welter, M.-L., Vidailhet, M., Daunizeau, J., \& Pessiglione, M. (2016). Computational Dissection of Dopamine Motor and Motivational Functions in Humans. The Journal of Neuroscience, 36(25), 6623-6633. https://doi.org/10.1523/JNEUROSCI.3078-15.2016

Le Heron, C., Plant, O., Manohar, S., Ang, Y.-S., Jackson, M., Lennox, G., Hu, M. T., \& Husain, M. (2018). Distinct effects of apathy and dopamine on effort-based decision-making in Parkinson's disease. Brain, 141(5), 1455-1469. https://doi.org/10.1093/brain/awy110

Lenth, R., Singmann, H., Love, J., Buerkner, P., \& Herve, M. (2020). emmeans: Estimated Marginal Means, aka Least-Squares Means. https://CRAN.R-project.org/package=emmeans

Levy, R., \& Dubois, B. (2005). Apathy and the Functional Anatomy of the Prefrontal Cortex-Basal Ganglia Circuits. Cerebral Cortex, 16(7), 916-928. https://doi.org/10.1093/cercor/bhj043

Lewis, S. J. G., Slabosz, A., Robbins, T. W., Barker, R. A., \& Owen, A. M. (2005). Dopaminergic basis for deficits in working memory but not attentional set-shifting in Parkinson's disease. Neuropsychologia, 43(6), 823-832. https://doi.org/10.1016/j.neuropsychologia.2004.10.001

Long, J. A. (2019). interactions: Comprehensive, User-Friendly Toolkit for Probing Interactions. https://cran.r-project.org/package=interactions

Loued-Khenissi, L., \& Preuschoff, K. (2015). Apathy and noradrenaline: Silent partners to mild cognitive impairment in Parkinson's disease? Current Opinion in Neurology, 28(4), 344-350. https://doi.org/10.1097/WCO.0000000000000218

Ly, A., Boehm, U., Heathcote, A., Turner, B. M., Forstmann, B., Marsman, M., \& Matzke, D. (2017). A Flexible and Efficient Hierarchical Bayesian Approach to the Exploration of Individual Differences in Cognitive-model-based Neuroscience. In A. A. Moustafa (Ed.), Computational Models of Brain and Behavior (pp. 467-479). John Wiley \& Sons, Ltd. https://doi.org/10.1002/9781119159193.ch34

Macerollo, A., Chen, J.-C., Korlipara, P., Foltynie, T., Rothwell, J., Edwards, M. J., \& Kilner, J. M. (2016). Dopaminergic treatment modulates sensory attenuation at the onset of the movement in Parkinson's disease: A test of a new framework for bradykinesia. Movement Disorders, 31(1), 143-146. https://doi.org/10.1002/mds.26493

Makowski, D., Ben-Shachar, M., \& Lüdecke, D. (2019). bayestestR: Describing Effects and their Uncertainty, Existence and Significance within the Bayesian Framework. Journal of Open Source Software, 4(40), 1541. https://doi.org/10.21105/joss.01541

Marin, R. S. (1991). Apathy: A neuropsychiatric syndrome. The Journal of Neuropsychiatry and Clinical Neurosciences, 3(3), 243-254. https://doi.org/10.1176/jnp.3.3.243

Martinez-Martin, P., Falup-Pecurariu, C., Rodriguez-Blazquez, C., Serrano-Dueñas, M., Carod Artal, F. J., Rojo Abuin, J. M., \& Aarsland, D. (2011). Dementia associated with Parkinson's disease: Applying the Movement Disorder Society Task Force criteria. Parkinsonism \& Related Disorders, 17(8), 621624. https://doi.org/10.1016/j.parkreldis.2011.05.017

McClure, S. M., Gilzenrat, M. S., \& Cohen, J. D. (2006). An exploration-exploitation model based on norepinepherine and dopamine activity. In B. Schölkopf, J. C. Platt, \& Y. Weiss (Eds.), Advances in Neural Information Processing Systems (Vol. 18, pp. 867-874). MIT Press.

McGuire, J. T., Nassar, M. R., Gold, J. I., \& Kable, J. W. (2014). Functionally Dissociable Influences on Learning Rate in a Dynamic Environment. Neuron, 84(4), 870-881. https://doi.org/10.1016/j.neuron.2014.10.013

Meder, D., Herz, D. M., Rowe, J. B., Lehéricy, S., \& Siebner, H. R. (2019). The role of dopamine in the brain-Lessons learned from Parkinson's disease. NeuroImage, 190, 79-93. https://doi.org/10.1016/j.neuroimage.2018.11.021 
medRxiv preprint doi: https://doi.org/10.1101/2021.07.04.21259922; this version posted July 6 , 2021. The copyright holder for this preprint (which was not certified by peer review) is the author/funder, who has granted medRxiv a license to display the preprint in perpetuity. It is made available under a CC-BY 4.0 International license .

Mioshi, E., Dawson, K., Mitchell, J., Arnold, R., \& Hodges, J. R. (2006). The Addenbrooke's Cognitive Examination Revised (ACE-R): A brief cognitive test battery for dementia screening. International Journal of Geriatric Psychiatry, 21(11), 1078-1085. https://doi.org/10.1002/gps.1610

Moore, R. Y., \& Bloom, F. E. (1979). Central Catecholamine Neuron Systems: Anatomy and Physiology of the Norepinephrine and Epinephrine Systems. Annual Review of Neuroscience, 2(1), 113-168. https://doi.org/10.1146/annurev.ne.02.030179.000553

Moran, R. J., Campo, P., Symmonds, M., Stephan, K. E., Dolan, R. J., \& Friston, K. J. (2013). Free Energy, Precision and Learning: The Role of Cholinergic Neuromodulation. Journal of Neuroscience, 33(19), 8227-8236. https://doi.org/10.1523/JNEUROSCI.4255-12.2013

Moran, R. J., Symmonds, M., Dolan, R. J., \& Friston, K. J. (2014). The Brain Ages Optimally to Model Its Environment: Evidence from Sensory Learning over the Adult Lifespan. PLoS Computational Biology, 10(1), e1003422. https://doi.org/10.1371/journal.pcbi.1003422

Morey, R. D., Rouder, J. N., Jamil, T., Urbanek, S., Forner, K., \& Ly, A. (2018). BayesFactor: Computation of Bayes Factors for Common Designs. https://CRAN.R-project.org/package=BayesFactor

Muhammed, K., Manohar, S., Yehuda, M. B., Chong, T. T.-J., Tofaris, G., Lennox, G., Bogdanovic, M., Hu, M., \& Husain, M. (2016). Reward sensitivity deficits modulated by dopamine are associated with apathy in Parkinson's disease. Brain, 139(10), 2706-2721. https://doi.org/10.1093/brain/aww188

Muller, T. H., Mars, R. B., Behrens, T. E., \& O'Reilly, J. X. (2019). Control of entropy in neural models of environmental state. ELife, 8, e39404. https://doi.org/10.7554/eLife.39404

Murley, A. G., Coyle-Gilchrist, I., Rouse, M. A., Jones, P. S., Li, W., Wiggins, J., Lansdall, C. J., Rodríguez, P. V., Wilcox, A., Tsvetanov, K. A., Patterson, K., Lambon Ralph, M. A., \& Rowe, J. B. (2020). Redefining the multidimensional clinical phenotypes of frontotemporal lobar degeneration syndromes. Brain, 143(5), 1555-1571. https://doi.org/10.1093/brain/awaa097

Nasreddine, Z. S., Phillips, N. A., Bédirian, V., Charbonneau, S., Whitehead, V., Collin, I., Cummings, J. L., $\&$ Chertkow, H. (2005). The Montreal Cognitive Assessment, MoCA: A Brief Screening Tool For Mild Cognitive Impairment. Journal of the American Geriatrics Society, 53(4), 695-699. https://doi.org/10.1111/j.1532-5415.2005.53221.x

Nassar, M. R., Rumsey, K. M., Wilson, R. C., Parikh, K., Heasly, B., \& Gold, J. I. (2012). Rational regulation of learning dynamics by pupil-linked arousal systems. Nature Neuroscience, 15(7), 1040-1046. https://doi.org/10.1038/nn.3130

Nieuwenhuis, S., Gilzenrat, M. S., Holmes, B. D., \& Cohen, J. D. (2005). The Role of the Locus Coeruleus in Mediating the Attentional Blink: A Neurocomputational Theory. Journal of Experimental Psychology: General, 134(3), 291-307. https://doi.org/10.1037/0096-3445.134.3.291

Niv, Y., Daw, N. D., Joel, D., \& Dayan, P. (2007). Tonic dopamine: Opportunity costs and the control of response vigor. Psychopharmacology, 191(3), 507-520. https://doi.org/10.1007/s00213-006-0502-4

O'Callaghan, C., Hezemans, F. H., Ye, R., Rua, C., Jones, P. S., Murley, A. G., Holland, N., Regenthal, R., Tsvetanov, K. A., Wolpe, N., Barker, R. A., Williams-Gray, C. H., Robbins, T. W., Passamonti, L., \& Rowe, J. B. (2021). Locus coeruleus integrity and the effect of atomoxetine on response inhibition in Parkinson's disease. Brain. https://doi.org/10.1093/brain/awab142

O’Reilly, J. X., Schuffelgen, U., Cuell, S. F., Behrens, T. E. J., Mars, R. B., \& Rushworth, M. F. S. (2013). Dissociable effects of surprise and model update in parietal and anterior cingulate cortex. Proceedings of the National Academy of Sciences, 110(38), E3660-E3669.

https://doi.org/10.1073/pnas.1305373110

Parr, T., \& Friston, K. J. (2017). Uncertainty, epistemics and active inference. Journal of The Royal Society Interface, 14(136), 20170376. https://doi.org/10.1098/rsif.2017.0376

Passamonti, L., Lansdall, C. J., \& Rowe, J. B. (2018). The neuroanatomical and neurochemical basis of apathy and impulsivity in frontotemporal lobar degeneration. Current Opinion in Behavioral Sciences, 22, 14-20. https://doi.org/10.1016/j.cobeha.2017.12.015 
medRxiv preprint doi: https://doi.org/10.1101/2021.07.04.21259922; this version posted July 6 , 2021. The copyright holder for this preprint (which was not certified by peer review) is the author/funder, who has granted medRxiv a license to display the preprint in perpetuity.

It is made available under a CC-BY 4.0 International license .

Pelli, D. G. (1997). The VideoToolbox software for visual psychophysics: Transforming numbers into movies. Spatial Vision, 10(4), 437-442. https://doi.org/10.1163/156856897X00366

Petitet, P., Scholl, J., Attaallah, B., Drew, D., Manohar, S., \& Husain, M. (2021). The relationship between apathy and impulsivity in large population samples. Scientific Reports, 11(1), 4830. https://doi.org/10.1038/s41598-021-84364-w

Pifl, C., Kish, S. J., \& Hornykiewicz, O. (2012). Thalamic noradrenaline in Parkinson's disease: Deficits suggest role in motor and non-motor symptoms. Movement Disorders, 27(13), 1618-1624. https://doi.org/10.1002/mds.25109

Poewe, W., Seppi, K., Tanner, C. M., Halliday, G. M., Brundin, P., Volkmann, J., Schrag, A.-E., \& Lang, A. E. (2017). Parkinson disease. Nature Reviews Disease Primers, 3(1), 1-21. https://doi.org/10.1038/nrdp.2017.13

Pouget, A., Beck, J. M., Ma, W. J., \& Latham, P. E. (2013). Probabilistic brains: Knowns and unknowns. Nature Neuroscience, 16(9), 1170-1178. https://doi.org/10.1038/nn.3495

Priovoulos, N., Jacobs, H. I. L., Ivanov, D., Uludag, K., Verhey, F. R. J., \& Poser, B. A. (2018). Highresolution in vivo imaging of human locus coeruleus by magnetization transfer MRI at 3T and 7T. NeuroImage, 168, 427-436. https://doi.org/10.1016/j.neuroimage.2017.07.045

R Core Team. (2019). R: A Language and Environment for Statistical Computing. R Foundation for Statistical Computing. https://www.R-project.org/

Rae, C. L., Nombela, C., Rodríguez, P. V., Ye, Z., Hughes, L. E., Jones, P. S., Ham, T., Rittman, T., CoyleGilchrist, I., Regenthal, R., Sahakian, B. J., Barker, R. A., Robbins, T. W., \& Rowe, J. B. (2016). Atomoxetine restores the response inhibition network in Parkinson's disease. Brain, 139( $\mathrm{Pt} 8), 2235$ 2248. https://doi.org/10.1093/brain/aww138

Ramstead, M. J., Kirchhoff, M. D., \& Friston, K. J. (2020). A tale of two densities: Active inference is enactive inference. Adaptive Behavior, 28(4), 225-239. https://doi.org/10.1177/1059712319862774

Reimer, J., McGinley, M. J., Liu, Y., Rodenkirch, C., Wang, Q., McCormick, D. A., \& Tolias, A. S. (2016). Pupil fluctuations track rapid changes in adrenergic and cholinergic activity in cortex. Nature Communications, 7(1), 13289. https://doi.org/10.1038/ncomms13289

Robbins, T. W. (2000). Chemical neuromodulation of frontal-executive functions in humans and other animals. Experimental Brain Research, 133(1), 130-138. https://doi.org/10.1007/s002210000407

Robbins, T. W., \& Arnsten, A. F. T. (2009). The Neuropsychopharmacology of Fronto-Executive Function: Monoaminergic Modulation. Annual Review of Neuroscience, 32(1), 267-287. https://doi.org/10.1146/annurev.neuro.051508.135535

Robert, P. H., Onyike, C. U., Leentjens, A. F. G., Dujardin, K., Aalten, P., Starkstein, S. E., Verhey, F. R. J., Yessavage, J., Clement, J. P., Drapier, D., Bayle, F., Benoit, M., Boyer, P., Lorca, P. M., Thibaut, F., Gauthier, S., Grossberg, G., Vellas, B., \& Byrne, J. (2009). Proposed diagnostic criteria for apathy in Alzheimer's disease and other neuropsychiatric disorders. European Psychiatry, 24(2), 98-104. https://doi.org/10.1016/j.eurpsy.2008.09.001

Rouder, J. N., Morey, R. D., Speckman, P. L., \& Province, J. M. (2012). Default Bayes factors for ANOVA designs. Journal of Mathematical Psychology, 56(5), 356-374.

https://doi.org/10.1016/j.jmp.2012.08.001

Rouder, J. N., Speckman, P. L., Sun, D., Morey, R. D., \& Iverson, G. (2009). Bayesian t tests for accepting and rejecting the null hypothesis. Psychonomic Bulletin \& Review, 16(2), 225-237. https://doi.org/10.3758/PBR.16.2.225

Rua, C., O’Callaghan, C., Ye, R., Hezemans, F. H., Passamonti, L., Jones, P. S., Williams, G. B., Rodgers, C. T., \& Rowe, J. B. (2021). Substantia nigra ferric overload and neuromelanin loss in Parkinson's disease measured with 7T MRI [Preprint]. Neurology. https://doi.org/10.1101/2021.04.13.21255416 
medRxiv preprint doi: https://doi.org/10.1101/2021.07.04.21259922; this version posted July 6 , 2021. The copyright holder for this preprint (which was not certified by peer review) is the author/funder, who has granted medRxiv a license to display the preprint in perpetuity. It is made available under a CC-BY 4.0 International license .

Sales, A. C., Friston, K. J., Jones, M. W., Pickering, A. E., \& Moran, R. J. (2019). Locus Coeruleus tracking of prediction errors optimises cognitive flexibility: An Active Inference model. PLOS Computational Biology, 15(1), e1006267. https://doi.org/10.1371/journal.pcbi.1006267

Sauer, J.-M., Ring, B. J., \& Witcher, J. W. (2005). Clinical pharmacokinetics of atomoxetine. Clinical Pharmacokinetics, 44(6), 571-590. https://doi.org/10.2165/00003088-200544060-00002

Scatton, B., Javoy-Agid, F., Rouquier, L., Dubois, B., \& Agid, Y. (1983). Reduction of cortical dopamine, noradrenaline, serotonin and their metabolites in Parkinson's disease. Brain Research, 275(2), 321328. https://doi.org/10.1016/0006-8993(83)90993-9

Schultz, W. (2015). Neuronal Reward and Decision Signals: From Theories to Data. Physiological Reviews, 95(3), 853-951. https://doi.org/10.1152/physrev.00023.2014

Schultz, W., Dayan, P., \& Montague, P. R. (1997). A Neural Substrate of Prediction and Reward. Science, 275(5306), 1593-1599. https://doi.org/10.1126/science.275.5306.1593

Schwartenbeck, P., FitzGerald, T. H. B., Mathys, C., Dolan, R., \& Friston, K. (2015). The Dopaminergic Midbrain Encodes the Expected Certainty about Desired Outcomes. Cerebral Cortex, 25(10), 3434 3445. https://doi.org/10.1093/cercor/bhu159

Scott, B. M., Eisinger, R. S., Burns, M. R., Lopes, J., Okun, M. S., Gunduz, A., \& Bowers, D. (2020). Cooccurrence of apathy and impulse control disorders in Parkinson disease. Neurology, 95(20), e2769e2780. https://doi.org/10.1212/WNL.0000000000010965

Seamans, J. K., \& Yang, C. R. (2004). The principal features and mechanisms of dopamine modulation in the prefrontal cortex. Progress in Neurobiology, 74(1), 1-58. https://doi.org/10.1016/j.pneurobio.2004.05.006

Servan-Schreiber, D., Printz, H., \& Cohen, J. (1990). A network model of catecholamine effects: Gain, signalto-noise ratio, and behavior. Science, 249(4971), 892-895. https://doi.org/10.1126/science.2392679

Singmann, H., Bolker, B., Westfall, J., Aust, F., \& Ben-Shachar, M. S. (2020). afex: Analysis of Factorial Experiments. https://CRAN.R-project.org/package $=$ afex

Singmann, H., \& Kellen, D. (2019). An Introduction to Mixed Models for Experimental Psychology. In D. Spieler \& E. Schumacher (Eds.), New Methods in Cognitive Psychology (1st ed., pp. 4-31). Routledge.

Sinha, N., Manohar, S., \& Husain, M. (2013). Impulsivity and apathy in Parkinson's disease. Journal of Neuropsychology, 7(2), 255-283. https://doi.org/10.1111/jnp.12013

Stan Development Team. (2019). RStan: The R interface to Stan. http://mc-stan.org/

Starkstein, S. E., Jorge, R., Mizrahi, R., \& Robinson, R. G. (2006). A prospective longitudinal study of apathy in Alzheimer's disease. Journal of Neurology, Neurosurgery \& Psychiatry, 77(1), 8. https://doi.org/10.1136/jnnp.2005.069575

Starkstein, S. E., Mayberg, H. S., Preziosi, T. J., Andrezejewski, P., Leiguarda, R., \& Robinson, R. G. (1992). Reliability, validity, and clinical correlates of apathy in Parkinson's disease. The Journal of Neuropsychiatry and Clinical Neurosciences, 4(2), 134-139. https://doi.org/10.1176/jnp.4.2.134

Surmeier, D. J., Obeso, J. A., \& Halliday, G. M. (2017). Selective neuronal vulnerability in Parkinson disease. Nature Reviews Neuroscience, 18(2), 101-113. https://doi.org/10.1038/nrn.2016.178

Swanson, C. J., Perry, K. W., Koch-Krueger, S., Katner, J., Svensson, K. A., \& Bymaster, F. P. (2006). Effect of the attention deficit/hyperactivity disorder drug atomoxetine on extracellular concentrations of norepinephrine and dopamine in several brain regions of the rat. Neuropharmacology, 50(6), 755760. https://doi.org/10.1016/j.neuropharm.2005.11.022

Szabadi, E. (2013). Functional neuroanatomy of the central noradrenergic system. Journal of Psychopharmacology, 27(8), 659-693. https://doi.org/10.1177/0269881113490326

Teichert, J., Rowe, J. B., Ersche, K. D., Skandali, N., Sacher, J., Aigner, A., \& Regenthal, R. (2020). Determination of atomoxetine or escitalopram in human plasma by HPLC: Applications in 
medRxiv preprint doi: https://doi.org/10.1101/2021.07.04.21259922; this version posted July 6 , 2021. The copyright holder for this preprint (which was not certified by peer review) is the author/funder, who has granted medRxiv a license to display the preprint in perpetuity.

It is made available under a CC-BY 4.0 International license .

neuroscience research studies. International Journal of Clinical Pharmacology and Therapeutics, 58(8), 426-438. PubMed. https://doi.org/10.5414/cp203705

Tervo, D. G. R., Proskurin, M., Manakov, M., Kabra, M., Vollmer, A., Branson, K., \& Karpova, A. Y. (2014). Behavioral Variability through Stochastic Choice and Its Gating by Anterior Cingulate Cortex. Cell, 159(1), 21-32. https://doi.org/10.1016/j.cell.2014.08.037

Thaut, M. H., McIntosh, G. C., Rice, R. R., Miller, R. A., Rathbun, J., \& Brault, J. M. (1996). Rhythmic auditory stimulation in gait training for Parkinson's disease patients. Movement Disorders, 11(2), 193-200. https://doi.org/10.1002/mds.870110213

Tomlinson, C. L., Stowe, R., Patel, S., Rick, C., Gray, R., \& Clarke, C. E. (2010). Systematic review of levodopa dose equivalency reporting in Parkinson's disease. Movement Disorders, 25(15), 26492653. https://doi.org/10.1002/mds.23429

Toschi, C., Hervig, M. E.-S., Moazen, P., Parker, M. G., Dalley, J. W., Gether, U., \& Robbins, T. W. (2021). Adaptive aspects of impulsivity and interactions with effects of catecholaminergic agents in the 5choice serial reaction time task: Implications for ADHD. Psychopharmacology. https://doi.org/10.1007/s00213-021-05883-y

Tredici, K. D., \& Braak, H. (2013). Dysfunction of the locus coeruleus-norepinephrine system and related circuitry in Parkinson's disease-related dementia. Journal of Neurology, Neurosurgery \& Psychiatry, 84(7), 774-783. https://doi.org/10.1136/jnnp-2011-301817

Tschantz, A., Seth, A. K., \& Buckley, C. L. (2020). Learning action-oriented models through active inference. PLOS Computational Biology, 16(4), e1007805. https://doi.org/10.1371/journal.pcbi.1007805

Tustison, N. J., Cook, P. A., Klein, A., Song, G., Das, S. R., Duda, J. T., Kandel, B. M., van Strien, N., Stone, J. R., Gee, J. C., \& Avants, B. B. (2014). Large-scale evaluation of ANTs and FreeSurfer cortical thickness measurements. NeuroImage, 99, 166-179.

https://doi.org/10.1016/j.neuroimage.2014.05.044

Varazzani, C., San-Galli, A., Gilardeau, S., \& Bouret, S. (2015). Noradrenaline and Dopamine Neurons in the Reward/Effort Trade-Off: A Direct Electrophysiological Comparison in Behaving Monkeys. Journal of Neuroscience, 35(20), 7866-7877. https://doi.org/10.1523/JNEUROSCI.0454-15.2015

Vehtari, A., Gelman, A., \& Gabry, J. (2017). Practical Bayesian model evaluation using leave-one-out crossvalidation and WAIC. Statistics and Computing, 27(5), 1413-1432. https://doi.org/10.1007/s11222016-9696-4

Vilares, I., \& Kording, K. P. (2017). Dopaminergic medication increases reliance on current information in Parkinson's disease. Nature Human Behaviour, 1(8), 0129. https://doi.org/10.1038/s41562-017-0129

Warren, C. M., Eldar, E., van den Brink, R. L., Tona, K.-D., Wee, N. J. van der, Giltay, E. J., Noorden, M. S. van, Bosch, J. A., Wilson, R. C., Cohen, J. D., \& Nieuwenhuis, S. (2016). Catecholamine-Mediated Increases in Gain Enhance the Precision of Cortical Representations. Journal of Neuroscience, 36(21), 5699-5708. https://doi.org/10.1523/JNEUROSCI.3475-15.2016

Wayment, H. K., Schenk, J. O., \& Sorg, B. A. (2001). Characterization of Extracellular Dopamine Clearance in the Medial Prefrontal Cortex: Role of Monoamine Uptake and Monoamine Oxidase Inhibition. The Journal of Neuroscience, 21(1), 35-44. https://doi.org/10.1523/JNEUROSCI.21-01-00035.2001

Weintraub, D., Hoops, S., Shea, J. A., Lyons, K. E., Pahwa, R., Driver-Dunckley, E. D., Adler, C. H., Potenza, M. N., Miyasaki, J., Siderowf, A. D., Duda, J. E., Hurtig, H. I., Colcher, A., Horn, S. S., Stern, M. B., \& Voon, V. (2009). Validation of the questionnaire for impulsive-compulsive disorders in Parkinson's disease. Movement Disorders, 24(10), 1461-1467. https://doi.org/10.1002/mds.22571

Weintraub, D., Mavandadi, S., Mamikonyan, E., Siderowf, A. D., Duda, J. E., Hurtig, H. I., Colcher, A., Horn, S. S., Nazem, S., Ten Have, T. R., \& Stern, M. B. (2010). Atomoxetine for depression and other neuropsychiatric symptoms in Parkinson disease. Neurology, 75(5), 448-455.

https://doi.org/10.1212/WNL.0b013e3181ebdd79 
medRxiv preprint doi: https://doi.org/10.1101/2021.07.04.21259922; this version posted July 6 , 2021. The copyright holder for this preprint (which was not certified by peer review) is the author/funder, who has granted medRxiv a license to display the preprint in perpetuity.

Wickham, H., Averick, M., Bryan, J., Chang, W., McGowan, L., François, R., Grolemund, G., Hayes, A., Henry, L., Hester, J., Kuhn, M., Pedersen, T., Miller, E., Bache, S., Müller, K., Ooms, J., Robinson, D., Seidel, D., Spinu, V., ... Yutani, H. (2019). Welcome to the Tidyverse. Journal of Open Source Software, 4(43), 1686. https://doi.org/10.21105/joss.01686

Wiese, W. (2017). Action Is Enabled by Systematic Misrepresentations. Erkenntnis, 82(6), 1233-1252. https://doi.org/10.1007/s10670-016-9867-x

Wolpe, N., Ingram, J. N., Tsvetanov, K. A., Geerligs, L., Kievit, R. A., Henson, R. N., Wolpert, D. M., CamCAN, \& Rowe, J. B. (2016). Ageing increases reliance on sensorimotor prediction through structural and functional differences in frontostriatal circuits. Nature Communications, 7(1).

https://doi.org/10.1038/ncomms 13034

Wolpe, N., Nombela, C., Ingram, J. N., Wolpert, D. M., Cam-CAN, \& Rowe, J. B. (2018). Sensory attenuation in Parkinson's disease is related to disease severity and dopamine dose. Scientific Reports, 8(1). https://doi.org/10.1038/s41598-018-33678-3

Wolpe, N., Nombela, C., \& Rowe, J. B. (2015). Dopaminergic modulation of positive expectations for goaldirected action: Evidence from Parkinson's disease. Frontiers in Psychology, 6. https://doi.org/10.3389/fpsyg.2015.01514

Wolpe, N., Wolpert, D. M., \& Rowe, J. B. (2014). Seeing what you want to see: Priors for one's own actions represent exaggerated expectations of success. Frontiers in Behavioral Neuroscience, 8. https://doi.org/10.3389/fnbeh.2014.00232

Xiang, Y., Graeber, T., Enke, B., \& Gershman, S. J. (2021). Confidence and central tendency in perceptual judgment. Attention, Perception, \& Psychophysics. https://doi.org/10.3758/s13414-021-02300-6

Ye, R., Rua, C., O’Callaghan, C., Jones, P. S., Hezemans, F. H., Kaalund, S. S., Tsvetanov, K. A., Rodgers, C. T., Williams, G., Passamonti, L., \& Rowe, J. B. (2021). An in vivo probabilistic atlas of the human locus coeruleus at ultra-high field. NeuroImage, 225, 117487.

https://doi.org/10.1016/j.neuroimage.2020.117487

Ye, Z., Altena, E., Nombela, C., Housden, C. R., Maxwell, H., Rittman, T., Huddleston, C., Rae, C. L., Regenthal, R., Sahakian, B. J., Barker, R. A., Robbins, T. W., \& Rowe, J. B. (2015). Improving Response Inhibition in Parkinson's Disease with Atomoxetine. Biological Psychiatry, 77(8), 740-748. https://doi.org/10.1016/j.biopsych.2014.01.024

Ye, Z., Rae, C. L., Nombela, C., Ham, T., Rittman, T., Jones, P. S., Rodríguez, P. V., Coyle-Gilchrist, I., Regenthal, R., Altena, E., Housden, C. R., Maxwell, H., Sahakian, B. J., Barker, R. A., Robbins, T. W., \& Rowe, J. B. (2016). Predicting beneficial effects of atomoxetine and citalopram on response inhibition in Parkinson's disease with clinical and neuroimaging measures: Predicting Treatment Response in PD. Human Brain Mapping, 37(3), 1026-1037. https://doi.org/10.1002/hbm.23087

Yu, A. J., \& Dayan, P. (2005). Uncertainty, Neuromodulation, and Attention. Neuron, 46(4), 681-692. https://doi.org/10.1016/j.neuron.2005.04.026

Zarow, C., Lyness, S. A., Mortimer, J. A., \& Chui, H. C. (2003). Neuronal Loss Is Greater in the Locus Coeruleus Than Nucleus Basalis and Substantia Nigra in Alzheimer and Parkinson Diseases. Archives of Neurology, 60(3), 337-341. https://doi.org/10.1001/archneur.60.3.337

Zoon, T. J. C., Rooijen, G., Balm, G. M. F. C., Bergfeld, I. O., Daams, J. G., Krack, P., Denys, D. A. J. P., \& Bie, R. M. A. (2021). Apathy Induced by Subthalamic Nucleus Deep Brain Stimulation in Parkinson's Disease: A Meta-Analysis. Movement Disorders, 36(2), 317-326. https://doi.org/10.1002/mds.28390 